\title{
BetWeen SHARED AND UNIQUe CONSTITUTIONAL TRAITS - The PORTUgueSe CONSTITUTIONAL TRADITION
}

\author{
Catarina Santos Botelho ${ }^{1}$
}

\begin{abstract}
I. COMMON CONSTITUTIONAL TRADITIONS

1. Common constitutional traditions: Foundations, content and society.

1.1. Introduction;

1.2. National constitutional 'identity' or national constitutional 'tradition'?

1.3. The Portuguese Constitution;

1.4. Constitutional tradition in the Portuguese Constitutional Court's jurisprudence.
\end{abstract}

2. Distinctive traits of Portuguese constitutionalism:

2.1. A unique hybrid constitutional justice system;

2.2. The world's longest unamendable clause;

2.3. The economic constitution

2.4. Perfectionism and prolixity of the fundamental rights catalogue

2.5. The insular autonomic regime;

2.6. Flexibility of the legal definition of the right to strike;

2.7. Prohibition of military/ paramilitary, racist or fascists organizations - Limits to pluralism?

2.8. A sui generis system of government and the government's power to legislate in all the subjects that are not reserved to the parliament;

2.9. Restrictiveness of referenda;

2.10. Universal Declaration of Human Rights as a constitutional continuum.

II. Fundamental Rights to Free SPeEch, Freedom of Movement and Judicial INDEPENDENCE;

1. Free speech

1.1. Constitutional standards of scrutiny for free speech;

1.2. Interplay between free speech and crimes of opinion, display of religious symbols, blasphemy, hate speech, holocaust denial, and burning of political symbols;

1.3. Free speech and new technologies;

1.4. Legal traditions on free speech.

2. Freedom of movement

2.1. Does EU law give room to an autonomous national regulation?

2.2. Legal traditions on freedom of movement.

3. Judicial independence

3.1. Judiciary organization in Portugal;

3.2. Judicial independence;

3.3. Legal traditions on judicial independence.

1 Assistant Professor (with tenure) and Department Chair of Constitutional Law at the Porto Faculty of Law, Universidade Católica Portuguesa; email: cbotelho@porto.ucp.pt I have benefited from helpful comments by Filipe César Marques, Manuel Fontaine Campos, Marta Nunes Vicente, and Nuno Garoupa. The usual disclaimers apply. 


\section{Common Constitutional Traditions}

\section{Common constitutional traditions: Foundations, content and society}

\subsection{Introduction}

Both the constitutional movement (XVIII) and the normative force of the constitution $(\mathrm{XX})$ have been caught up by "a constitutional storm, with the strong winds of globalization and supranational integration threating the current constitutional architecture". ${ }^{2}$ The constitutional space has become permeable to other legal sources, allowing spaces of "interconstitutionality" and putting the traditional role of the national constitution at risk. ${ }^{3}$ Human rights protection is no longer an exclusive responsibility of each state. ${ }^{4}$ It is now "porous" and encourages interjurisditional dialogue. ${ }^{5}$

Most international and European human rights legislation - such as the EU Charter of Fundamental Rights - was inspired on common constitutional traditions of their Member States. ${ }^{6}$ This kind of constitutional (global, regional and national) osmosis

\footnotetext{
2 C. S. Botelho, Os Direitos Sociais em Tempos de Crise - Ou Revisitar as Normas Programáticas, Almedina, 2015, p. 80.

${ }^{3}$ F. Balaguer Callejón, "El final de una época dorada. Una reflexión sobre la crisis económica y el declive del Derecho Constitucional nacional", Estudos em Homenagem ao Prof. Doutor José Joaquim Gomes Canotilho, vol. II, Coimbra Editora, 2012, pp. 99-121, p. 105, F. L. Pires, Introdução ao Direito Constitucional Europeu, Almedina, 1997, p. 18, and P. C. Rangel, "Tranconstitucionalismo versus interconstitucionalidade - Uma leitura crítica do pensamento 'transconstitucional' de Marcelo Neves", Tribunal Constitucional - 35. ${ }^{\circ}$ Aniversário da Constituição de 1976, vol. II, Coimbra Editora, 2012, pp. 151-174, p. 157.

${ }^{4}$ P. Häberle, Verfassungsvergleichung in europa-und weltbürgerlicher Absicht - Späte Schriften, Duncker \& Humblot, Berlin, 2009, p. 41, and R. Medeiros, A Constituição Portuguesa num contexto global, Universidade Católica Editora, Lisboa, 2015, pp. 360-365.

${ }^{5} \mathrm{~N}$. Walker, "The migration of constitutional ideas and the migration of the constitutional idea: the case of the EU", The Migration of Constitutional Ideas, Cambridge University Press, 2006, pp. 316-343, p. 317, N. Matz-Lück, "Europäische Rechtsakte und nationaler Grundrechtsschutz", Grundrechte und Grundfreiheiten im Mehrebensystem - Konkurrenzen und Interferenzen, Springer, 2012, pp. 161-201, pp. 188-192, and R. Geesmann, Soziale Grundrechte im deutschen und französischen Verfassunsgrecht und der Charta der Grundrechte der Europäischen Union - Eine rechtsvergleichende Untersuchung zu den Wirkdimensionen sozialer Grundrechte, Peter Lang, 2005, pp. 118-120, p. 273.

${ }^{6}$ A.-T. Hupka, Der Konventsentwurf für einen Vertrag über eine Verfassung für Europa - Eine britische Sicht, Duncker \& Humblot, 2010, p. 23, C. S. Botelho, "A recepção da Carta dos Direitos Fundamentais da União Europeia na ordem jurídico-constitucional portuguesa: uma dinâmica pro unione ou pro constitutione?", Liber Amicorum em homenagem ao Professor Doutor João Mota de Campos, Coimbra Editora, 2013, pp. 315-359, pp. 321-326, C. Tomuschat, "Der Verfassungsstaat im Geflecht der internationalen Beziehungen", Veröffentlichungen der Vereinigung der Deutschen Staatsrechtslehrer, 36, 1978, pp. 7-64, p. 50, G. Biaggini, "Die Idee der Verfassung - Neuausrichtung im Zeitalter der Globalisierung?”, Zeitschrift für Schweizerisches Recht, 119, 2000, pp. 445-476, p. 454, nt. 25, P. Häberle, Europäische Verfassungslehre, Nomos, Baden-Baden, 2011, p. 209, and U. Haltern, "Internationales Verfassungsrechts?", Archiv des öffentlichen Rechts, 128, 2003, pp. 511-557.
} 
reveals that "there is no apartheid" between national constitutionalism and European constitutionalism. ${ }^{7}$

Article 6, § 3 TUE clearly proclaims that "fundamental rights, as guaranteed by the European Convention for the Protection of Human Rights and Fundamental Freedoms and as they result from the constitutional traditions common to the Member States, shall constitute general principles of the Union's law.” J. J. Gomes Canotilho and Mariana Canotilho were undoubtedly right when they wrote that the appeal to common constitutional traditions "permits overcoming the a rigid approach of a "lower common denominator' and allows the densification of the European standard of fundamentality so as to provide a high level of rights' protection, adequate to EU law and in accordance with the constitutional law of the Member States". 8

Initially, European constitutionalism struggled with the resistance towards EU law, with some constitutional courts trying to shield their constitutions from EU supremacy. The expression "constitutional patriotism" (Verfassungspatriotismus) was baptized by Dolf Sternberger, in 1979. Some classical examples were the conservative jurisprudence of the German Constitutional Court, ${ }^{9}$ the "counter-limits" (contro-limiti) theory of the Italian Constitutional Court ${ }^{10}$, and the more recent Taricco saga.

Even so, the European resistance led by the Italian Constitutional Court started with less intensity as the German. In Taricco $I,{ }^{11}$ the focus was not a patriotic "identitybased language" against EU constitutional integration, but "the protection of the untouchable core of the constitutional legal order" which somehow unveils Europe's common constitutional heritage. ${ }^{12}$ However, in Taricco $I I,{ }^{13}$ the 'constitutional tradition'

\footnotetext{
${ }^{7}$ V. Moreira, "Constitucionalismo supranacional: a União Europeia depois do Tratado de Lisboa", Estudos em Homenagem ao Prof. Doutor José Joaquim Gomes Canotilho, vol. II, cit., pp. 503-539, p. 536.

8 J. J. G. Canotilho and M. Canotilho, "Artigo 6", Tratado de Lisboa-Anotado e Comentado (ed. M. L. Porto \& G. Anastácio), Almedina, Coimbra, 2012, pp. 39-42, p. 42.

${ }^{9}$ The German Constitutional Court presented a list of core state powers immune to the influence of EU law (BVerfG, judgment 2 BvE 2/08; or BVerfG, judgment 2 BvR 2728/13).

${ }^{10}$ See Italian Constitutional Court, Judgment 183/1973. The idea of the counter-limits is that supranational norms violating the main principles of the Italian Constitution were not applicable in the Italian legal system. For an overview, see M. Cartabia, Principi Inviolabili e Integrazione Europea, Giuffrè, Lina, 1995. However, as F. Fabbrini and O. Pollicino, "Constitutional Identity in Italy: Institutional Disagreements at a Time of Political Change", Constitutional Identity in a Europe of Multilevel Constitutionalism (C. Calliess and G. v. d. Schyff), forthcoming 2019, highlight, "while the CC had recognised the theoretical existence of counter-limits to the supremacy of EU law, it clarified that such limits would be mostly hypothetical [Italian Constitutional Court, judgment 232/1989], and never invoked them in practice."

${ }^{11}$ C-105/14, 08.09.2015.

${ }^{12}$ F. Fabbrini and O. Pollicino, "Constitutional Identity in Italy... cit., ibidem.

${ }^{13}$ C-42/17, 05.12.2017.
} 
narrative switched to a 'constitutional identity'/sovereigntist reading of the Constitution. ${ }^{14}$

If the primacy of European Union law needed strong affirmation during the first conflictive decades ${ }^{15}$, nowadays we should not interpret it in an absolute tone. ${ }^{16}$ As I have written elsewhere: “( $i$ ) the Portuguese Constitution conveys to harmonize EU primacy with the protection of national identity, since the "fundamental principles of a democratic state based on the rule of law" are excepted from the principle of primacy; (ii) if, in some cases, the European Court of Justice (ECJ) has strongly affirmed primacy, ${ }^{17}$ in other cases it has also shown some plasticity in the understanding of primacy, choosing to assign application priority to the national norm, when it guarantees a higher level of protection; ${ }^{18}$ (iii) the static language of primacy and verticality has been replaced by a logic of cooperation based on horizontality - the interesting concepts of 'multilevel cooperation', 'model of articulation' and 'mutual learning' have been suggested for this purpose."19

In situations where the margin of national appreciation is narrower, the ECJ has been stricter in what regards the principle of EU primacy (cases of Melloni ${ }^{20}$ or Taricco I). Yet, in situations where the state had wider discretion, the ECJ has reasoned according to the idea of the maximum level of protection (case of Taricco II). ${ }^{21}$

\footnotetext{
${ }^{14}$ See A. Ruggeri, "Rapporti interordinamentali e conflitti tra identità costituzionali (traendo spunto dal caso Taricco)", Diritto penale contemporaneo, 2017, pp. 115-127, and F. Fabbrini and O. Pollicino, "Constitutional Identity in Italy... cit., ibidem.

${ }^{15}$ See ECJ Internationale Handelsgesellschaft, no. 11/70, 17.12.1970, para. 3.

16 A. von Bogdandy and S. Schill, "Overcoming absolute primacy: respect for national identity under Lisbon Treaty", Common Market Law Review, 48, 2011, pp. 1417-1453, p. 1419, and C. S. Botelho, “A recepção da Carta... cit., p. 340.

${ }^{17}$ Such as in cases C-144/04, Mangold (2005), C-399/09, Landtová (2009), and C-173/09, Elchinov (2010).

18 See cases C-27/00 e C-122/00, Omega (2002), C-112/00, Schmidberger (2003), C-402/05P and C415/05P, Kadi and Al Barakaat (2008), and C-62/14, Gauweiler (2015).

${ }^{19}$ C. S. Botelho, "Novo ou velho direito? - O direito ao esquecimento e o princípio da proporcionalidade no constitucionalismo global", Revista AB INSTANTIA, 7, 2018, pp. 49-71, pp. 59-60. More generally, see B.-O. Bryde, “The ECJ's fundamental rights jurisprudence - a milestone in transnational constitutionalism", The Past and the Future of EU Law - The Classics of EU Law Revisited on the 50th Anniversary of the Rome Treaty (ed. M. Poiares Maduro e L. Azulai), Hart Publishing, 2010, pp. 119-129, pp. 126-128, F. Schimmelfennig, "Competition and community: constitutional courts, rhetorical action, and the institutionalization of human rights in the European Union", Journal of European Public Policy, 13, 2006, pp. 1247-1264, p. 1252, G. L. Neuman, "Human Rights and Constitutional Rights: Harmony and Dissonance", Stanford Law Review, 55 (5), 2003, pp. 1863-1900, pp. 1863-1864, G. Ziegehorn, Der Einfluss der EMRK im Recht der EU-Grundrechtecharta - Genuin chartarechtlicher Grundrechtsschutz gemäß Art. 52 Abs. 3 GRCh, Duncker \& Humblot, Berlin, 2009, pp. 221-226, M. Delmas-Marty, Towards a Truly Common Law: Europe as a Laboratory for Legal Pluralism, Cambridge University Press, 2002, M. P. Maduro, "The Double Life of the Charter of Fundamental Rights", Economic and Social Rights Under the EU Charter of Fundamental Rights, Hart Publishing, 2003, pp. 269-299, p. 296, and V. C. Jackson, "Constitutional Comparisons: Convergence, Resistance, Engagement", Harvard Law Review, 119, 2005 , pp. 109-128.

${ }^{20}$ C-399/11, 26.02.2013.

21 For a critique, see M. Bassini and O. Pollicino, Defusing the Taricco Bomb through Fostering Constitutional Tolerance: All Roads Lead to Rome, 5 December 2017, Verfassungsblog:
} 
Although the EU lacks a formal constitutional text, it surely possesses a material constitution. To Miguel Poiares Maduro, the best attempt to theorize European constitutionalism was through constitutional pluralism (rule of law, protection of minorities, fundamental right's guarantees). ${ }^{22}$ In our current transitional period towards (what we hope to be) an increasing European constitutional integration, the appeal to the Member States' constitutional traditions is understandable and can be perceived as an attempt to "reconcile the irreconcilable". ${ }^{23}$

Hence, the idea of non-negotiable constitutional essentials, instead of creating systemic contradictions, can enhance the dialogue on material European integration. ${ }^{24}$ European Constitutional Law also includes "various constitutional spaces living side by side in the European space". ${ }^{25}$ 'Constitutional traditions' should be taken into consideration, the same way the European Court of Human Rights (ECHR) balances national singularities with human right's universalism through the margin of appreciation doctrine. ${ }^{26}$

What are the 'common constitutional traditions' enshrined in the dialogical relation between national constitutions and EU treaties? We can think of some: The repudiation of totalitarian and authoritarian regimes; the acceptance of a constitutional order beyond the nation-state; achievements of freedom, democracy, and peace; and the dignity of the human person. ${ }^{27}$

\subsection{National constitutional 'identity' or national constitutional 'tradition'?}

Ten years after the entry into force of the "identity clause", densified by the Lisbon Treaty (2009), we should reflect on its exact extent. Article 4, § 2 TEU states the

http://verfassungsblog.de/defusing-the-taricco-bomb-through-fostering-constitutional-tolerance-all-roadslead-to-rome/\#primary_menu_sandwich

${ }^{22}$ M. P. Maduro, "Constitutional Pluralism as the Theory of European Constitutionalism", Estudos em Homenagem ao Prof. Doutor José Joaquim Gomes Canotilho, III, cit., pp. 449-471, p. 450.

${ }^{23}$ A. Levade, "Identité constitutionnelle et exigence existentielle, comment concilier l'inconciliable", L'Union européenne: Union de droit, union des droits - Mélanges en l'honneur de Philippe Manin (eds. C. Boutayeb, J.-C. Masclet, S. Rodrigues \& H. Ruiz Fabri), Pedone, Paris, 2010, pp. 109-128.

${ }^{24}$ Similarly, A. Schillaci, "Caminos de la integración material: la comunitarización de los contralímites en la Decisión Sociéte Arcelor Atlantique et Lorraine del Conseil d'Etat", Revista de Derecho Constitucional Europeo, 8, 2007, pp. 323-352.

${ }^{25}$ F. Balaguer Callejón, "The dialectic relation between the national and the European constitutional identity in the framework of European Constitutional Law", UNIO - EU Law Journal, 3 (1), 2017, pp 1024, p. 12.

${ }^{26}$ C. S. Botelho, "Quo vadis 'doutrina da margem nacional de apreciação'? O amparo internacional dos direitos do homem face à universalização da justiça constitucional", Estudos Dedicados ao Professor Doutor Luís Alberto Carvalho Fernandes, I, Universidade Católica Editora, Lisboa, 2011, pp. 341-376.

${ }^{27}$ For the dignity of the human person, see Case C-36/02 Omega [2004] ECR I-09609. 
following: "The Union shall respect the equality of Member States before the Treaties as well as their national identities, inherent in their fundamental structures, political and constitutional, inclusive of regional and local self-government."

The principle of the respect of the national identities of Member States conveys that European political integration cannot annihilate national state' minimum core of political and constitutional self-determination. ${ }^{28}$ My point is that, whatever the scholarly stance adopted, 'national identity' should be understood as a cluster-concept that assembles a myriad of identities, such as cultural, linguistic and social identities or political, or economic ones. ${ }^{29}$

To some doctrine, 'constitutional identity' and 'national identity' are not overlapping concepts. ${ }^{30}$ Elke Cloots admits there may be "considerable overlap between a Member State's constitutional identity and its national identity as reflected in its fundamental structures"; however, she believes it would be "misguided to simply equate the predicate of the EU Treaty's identity clause with 'constitutional identity"". 31 To Anna Śledzińska-Simon, constitutional identity may intersect with national identity, "even though the former does not need a nation for its existence, nor does the latter need a state." 32

Article 4, § 2 expressly addresses Member States' national identities. However, the 2009 Lisbon Treaty seems to have encouraged not only the ECJ, ${ }^{33}$ but also states' constitutional courts to interpret it in the more restricted sovereignty-based 'constitutional identity'. ${ }^{34}$ In other words, constitutional identity is being resorted to outline the relations between national and supranational legal orders. ${ }^{35}$

As Fabbrini and Pollicino astutely point out, what divides 'constitutional tradition' and 'constitutional identity' is "not only a formal, linguistic, difference, but a substantive

\footnotetext{
${ }^{28}$ V. Moreira, “A CRP e a União Europeia”, Estudos em Homenagem ao Conselheiro Presidente Rui Moura Ramos, Almedina, Coimbra, vol. I, 2016, pp. 869-926, p. 884.

${ }^{29}$ Accordingly, F. de Quadros, “Artigo 4", Tratado de Lisboa-Anotado e Comentado, cit., pp. 33-35, p. 35.

${ }^{30}$ E. Cloots, "National Identity, Constitutional Identity, and Sovereignty in the EU", Netherlands Journal of Legal Philosophy, 45 (2), 2016, pp. 82-98. With a different approach, F. Balaguer Callejón, "The dialectic relation... cit., p. 15.

${ }^{31}$ E. Cloots, "National Identity, Constitutional Identity... cit., pp. 82-98, p. 93.

32 A. Śledzińska-Simon, "Constitutional identity in 3D: A model of individual, relational, and collective self and its application in Poland”, International Journal of Constitutional Law, 13 (1), 2015, pp. 124-155, p. 127.

33 Specifically, see case C-53/04, Marrosu and Sardino, Opinion of AG Poiares Maduro, § 40; case C399/11, Melloni, Opinion of AG Bot, $§ 137-8$ and 142; and case C-62/14, Gauweiler, Opinion of AG Cruz Villalón, § 59.

${ }^{34}$ See the examples given in E. Cloots, "National Identity, Constitutional Identity... cit., pp. 82-98, p. 84.

${ }^{35}$ F. Fabbrini and O. Pollicino, "Constitutional Identity in Italy... cit., ibidem.
} 
one" (...) The notion of constitutional tradition is by definition pluralistic in nature, whereas the reference to constitutional identity, by design, is not. ${ }^{36}$ In fact, if 'constitutional identity' appeals to a "constitutional-patriotic-based language", 'constitutional traditions' - "pluralistic and tolerant by design" - is in tune with "the current season of cooperative constitutionalism in Europe." 37

'Constitutional identity' is a legal concept open to many interpretations. ${ }^{38}$ The European Court of Justice (ECJ) endeavoured to clarify it, without success. ${ }^{39}$ In other situations, the ECJ has plainly avoided the subject, preferring other routes of argumentation. ${ }^{40}$

Does 'constitutional identity' mean the specific constitutional traits of each state, such as having a written or unwritten constitution, being a republic or a monarchy, ${ }^{41}$ the system of government, the protection of a State's official national language, ${ }^{42}$ and the extension of the right's catalogue? Or does it have something to do with the cultural context in which a constitution operates?

Michel Troper explains constitutional identity as a set of essential principles that protect constitutional integrity. ${ }^{43}$ To Francisco Balaguer Callejón constitutional identity is "linked to other national sovereignty concepts such as the primary constituent power, material limits and constitutional revision power", which hinder the process of supranational integration. ${ }^{44}$ Laurence Tribe very interestingly captures the sociological and undefined nature of this concept, when he writes that constitutional identity "cannot be objectively deduced or passively discerned in a view-point neutral way". ${ }^{5}$

\footnotetext{
${ }^{36}$ Idem, ibidem.

${ }^{37}$ Idem, ibidem. See also Federico Fabbrini and András Sajó, "The dangers of constitutional identity", European Law Journal, 2019, forthcoming.

${ }^{38}$ M. Rosenfeld, "Constitutional Identity", The Oxford Handbook of Comparative Constitutional Law (ed. M. Rosenfeld and A. Sajó), Oxford University Press, 2012, pp. 756-776.

${ }^{39}$ Case 4/73, J Nold KG v EC Commission, [1974] ECR 491, 507.

${ }^{40}$ In case C-208/09, Sayn-Wittgenstein, 22.12.2010, paragraphs 83 and 92, in question was the Austrian legislation that prohibits aristocratic titles. Although the ECJ recognized that this was part of Austria's constitutional identity, instead of addressing the identity clause, the case was sorted out through the application of the proportionality principle.

${ }^{41}$ Sayn-Wittgenstein, $\$ 92$.

${ }^{42}$ Case C-391/09, Runevič-Vardyn and Wardyn, $\S 86$.

${ }^{43}$ M. Troper, "Behind the Constitution? The Principle of Constitutional Identity in France", Constitutional Topography: Values and Constitutions (ed. A. Sajó and R. Uitz), Eleven International Pub., Portland, 2010, p. 202-

${ }^{44}$ F. Balaguer Callejón, "The dialectic relation... cit., p. 21.

${ }^{45}$ L. Tribe, "A Constitution We Are Amending: In Defense of a Retrained Judicial Role", Harvard Law Review, 97 (2), 1983, pp. 433-445, p. 440.
} 
For Gary J. Jacobsohn, constitutional identity is an armour against "constitutional disharmony". ${ }^{46}$ In a wider perspective, Michel Rosenfeld projects constitutional identity as a response to "dialectical mediation of existing, evolving, and projected conflicts and tensions between identity and difference. ${ }^{, 47}$ With this in mind, Rosenfeld advises the EU adjudicator to "seek commonalities among the constitutions of member states, thus focusing on similarities and analogies across national constitutions." 48 Accordingly, Anna Śledzińska-Simon concludes that constitutional identity may disclose "at least three dimensions of the self - the individual self, the relational self, and the collective self, which constantly interact with each other." 49

As a given constitutional identity is fluid, it can never be fully acknowledged in the present time. In some sense, it is always partially revealed, and it can evolve. Since 'constitutional identity' captures the "core or fundamental elements or values of a particular member state's constitutional order" 50 or 'the individuality or essence of an order" ${ }^{\prime \prime}$, we wonder: Is 'constitutional identity' a constitution inside the constitution and, therefore, immune to change?

\subsection{The Portuguese Constitution}

The Portuguese constitutional history can be summarized as such: constitutional distress in the $19^{\text {th }}$ century, followed by republican experience and long dictatorship in the $20^{\text {th }}$ century, transition to democracy in the $70 \mathrm{~s}$, with decades of democratic consolidation so far. ${ }^{52}$

The Portuguese Constitution (1976) is now 43 years old and received many foreign influences. ${ }^{53}$ The German Grundgesetz (1949) and the Italian Constitution (1947) clearly influenced its fundamental rights protection. The impressive extent of the social rights catalogue and economic constitution were inherited from the ex-Soviet Union

\footnotetext{
${ }^{46}$ G. J. Jacobsohn, Constitutional Identity, Harvard University Press, 2010, pp. 87-88.

${ }^{47}$ M. Rosenfeld, "Constitutional Identity”, cit., pp. 756-776, p. 762.

${ }^{48}$ Idem, p. 772.

${ }^{49}$ A. Śledzińska-Simon, "Constitutional identity in 3D... cit., p. 128.

${ }^{50}$ F. Fabbrini and O. Pollicino, "Constitutional Identity in Italy... cit., ibidem.

51 G. van der Schyff, "EU Member State constitutional identity: a comparison of Germany and the Netherlands as polar opposites", Zeitschrift für ausländisches öffentliches Recht und Völkerrecht, 76, 2016, pp. 167-190, p. 169.

${ }_{52}$ C. S. Botelho, "Constitutional narcissism on the couch of psychoanalysis... cit., pp. 368-369.

53 C. S. Botelho, "Is there a middle ground between constitutional patriotism and constitutional cosmopolitanism? The Portuguese Constitutional Court and the use of foreign (case) law" in Giuseppe Franco Ferrari (Ed.), Judicial Cosmopolitanism - The Use of Foreign Law in Contemporary Constitutional Systems, Brill, 2019, pp. 424-448, pp. 425-426.
} 
constitutionalism. The semi-presidential system of government was inspired in the French constitutionalism, and the "Provedor de Justiça" (Ombudsperson) has a clear inspiration in the Nordic constitutional systems.

The Portuguese Constitutional Court (PCC), created in 1982, is at the top of the constitutional hierarchy. Regarding the PCC competences, it is relevant to underline that the Court belongs to the European constitutional court's "family", such as the courts located in Karlsruhe, Rome, Madrid or Zagreb. ${ }^{54}$ As I will try to explain in the following pages, the Portuguese model is a clear vertical model of judicial justice, with a constitutional court at the top of the hierarchy of norm constitutionality, albeit having some horizontal characteristics, since all the courts have the power not to apply a rule they deem unconstitutional. Therefore, as the PCC has no constitutional review monopoly, ordinary courts are also "agents of constitutional justice". 55

Spanish scholar Francisco Balaguer Callejón points out that the Portuguese example can illuminate the debate on the concept of 'constitutional identity'. ${ }^{56}$ Although the first two amendments of the Portuguese Constitution (in 1982 and 1989) performed drastic changes, the majority of the doctrine argues that its 'constitutional identity' (such as the rule of law, democracy, and the solidarity principle) did not change. ${ }^{57}$

To me, though, one should at least ponder whether those constitutional amendments operated a "constitutional dismemberment". According to Richard Albert, a "constitutional dismemberment" is a deliberate effort to transform "the identity, the fundamental values or the architecture" of the constitution "without breaking legal continuity." ${ }^{\circ 8}$ I find it hard to accept that the Constitution has remained the same, for three reasons: $(i)$ the original version of the Portuguese Constitution had such a heavy ideological weight of Marxist-Leninist content, that, if not changed, could have commuted into left-wing authoritarianism ${ }^{59}$; (ii) "the brave steps towards ideological and

\footnotetext{
${ }^{54}$ P. Häberle, Verfassungsvergleichung in europa-und weltbürgerlicher Absicht ... cit., pp. 61-62.

55 J. Mendes-Constante, "Les principes constitutionnels et l'organisation juridictionnelle - L'exemple du Portugal, Cahiers du Conseil Constitutionnel, 14, 2003, pp. 97-ff, p. 99 (2003). See also G. A. Ribeiro, "Judicial Review of Legislation in Portugal: A Brief Genealogy", Constitutional History: Comparative Perspectives (ed. Francesco Biag, Justin O. Frosini and Jason Mazzone), 2019, forthcoming, on file with the author).

${ }^{56}$ F. Balaguer Callejón, "The dialectic relation... cit., p. 21.

${ }^{57}$ See J. Miranda, “A originalidade e as principais características da Constituição Portuguesa”, Cuestiones Constitucionales, 16, 2007, pp. 253-280, p. 278, and J. J. G. Canotilho, Direito Constitucional e Teoria da Constituição, Almedina, Coimbra, 1998, p. 203.

${ }^{58}$ R. Albert, "Constitutional Amendment and Dismemberment", Yale Journal of International Law, 43 (1), 2018, pp. 1-84

${ }^{59}$ C. S. Botelho, "Aspirational constitutionalism, social rights prolixity and judicial activism: trilogy or trinity?”, Comparative Constitutional Law and Administrative Law Quarterly, 3 (4), 2017, pp. 62-87, p.
} 
political neutralization of the constitutional amendments of 1982 and 1989 reshaped the Portuguese Constitution and made it consonant with the substantive requirements of a truly democratic Rule of Law"60; (iii) and, as PCC Justice Gonçalo Almeida Ribeiro wrote, "it is a romantic misconception to assume the perfect democratic genesis of the Portuguese constitutional system." ${ }^{1}$ The PCC was created in 1982, replacing the "Council of revolution", a military organ with powers of constitutional review. ${ }^{62}$

Even if the original version of the Portuguese constitution (1976) contemplated a notorious eternity/entrenchment clause (former article 290), the truth is that "some of these provisions were indeed modified or removed in the 1989 constitutional amendment process. This occurred without major disagreement from the political organs, scholars or the judiciary." ${ }^{\prime 63}$ To Balaguer Callejón, this example reveals that "it is precisely the pluralist democracy that may be essentially identified with the constitutional identity and contrarily to concrete contents of the legal-constitutional system", that can be changed through constitutional amendment. ${ }^{64}$

The Portuguese constitution suffers from a dysfunctionality I labelled "constitutional narcissism". ${ }^{65}$ The narcissism of the Portuguese foundational moment meant a substantial divorce from the past and triggered the ideological compromise of transitioning to a classless society. The Portuguese Constitution of 1976, being one of the last postmodern revolutionary Constitutions (a destruens followed by a construens), is a defensive text, with singularities that set it apart from the rest of the European

65, J. C. da Costa, "Tribunal Constitucional e debate público", 40 Anos de Políticas de Justiça em Portugal, Almedina, Coimbra, 2016, pp. 113-141, p. 120, and J. Miranda, Da Revolução à Constituição - Memórias da Assembleia Constituinte, Principia, 2015, pp. 181-272.

${ }^{60}$ C. S. Botelho, "Constitutional narcissism on the couch of psychoanalysis... cit., p. 360. See also L.P.P. Coutinho, A Autoridade Moral da Constituição - Da Fundamentação da Validade do Direito Constitucional, Coimbra, Coimbra Editora, 2009, pp. 429-450, and M. L. Amaral, "Problemas da Judicial Review em Portugal", Themis, VI, 2005, pp. 67-90, p. 88.

${ }^{61}$ G. A. Ribeiro, "O paradoxo democrático na constituição portuguesa de 1976", Estudos em Homenagem ao Presidente Rui Moura Ramos (eds. M.L. Amaral \& S.P. Bettencourt), Coimbra, Almedina, 2016, pp. 121-148, p. 138.

62 A. R. Mendes, "O Conselho da Revolução e a Comissão Constitucional na fiscalização da constitucionalidade das leis: 1976-1983", Portugal: O Sistema Político e Constitucional 1974-1987, Imprensa de Ciências Sociais, 1989, pp. 925-940, K. Maxwell, The Making of Portuguese Democracy, Cambridge University Press, 1997, pp. 109-113, and pp. 158-178, M. L. Amaral and R. A. Pereira, "Um tribunal como os outros. Justiça constitucional e interpretação da constituição", Estudos em Homenagem ao Conselheiro Presidente Rui Moura Ramos, Almedina, Coimbra, 2016, pp. 381-442, pp. 420-422, and L. N. de Almeida, "Da politização da justiça à justicialização da política - do Conselho da Revolução ao Tribunal Constitucional", 20 Anos da Constituição de 1976, Coimbra Editora, Coimbra, 2000, pp. 277-289.

${ }^{63}$ C. S. Botelho, "Constitutional narcissism on the couch of psychoanalysis... cit., p. 345.

${ }^{64}$ F. Balaguer Callejón, "The dialectic relation... cit., p. 23.

${ }^{65}$ C. S. Botelho, "Constitutional narcissism on the couch of psychoanalysis: Constitutional unamendability in Portugal and Spain", European Journal of Law Reform, 21 (3), 2019, pp. 346-376. 
constitutions. Its constitutional defensiveness is revealed by the long unamendable clause (article 288), the prolix catalogue of social rights, one of the widest social rights catalogue in the world and probably the widest in Europe (articles 58 to 79$),{ }^{66}$ and the detailed economical constitution (articles 80 to 107$).{ }^{67}$

As I will address later (II. 2.1.) The PCC has not bluntly stated the supremacy of EU law over the Constitution, ${ }^{68}$ although it has declared that the legislative power must respect the obligations derived from EU Law. ${ }^{69} \mathrm{I}$ dare say the PCC is not only "one of the most cosmopolitan constitutional courts in the world" ${ }^{70}$, open to multilevel judicial dialogue, but also a Europe-friendly court. ${ }^{71}$ With this in mind, Francisco Pereira Coutinho and Nuno Piçarra assert that the PCC "seems to follow the generalized perception within Portuguese legal doctrine that the core legal values of the Portuguese Constitution are shared by the EU legal order and, therefore, it is unlikely that an EU legal act will go against the Constitution."72

\subsection{Constitutional tradition in the Portuguese Constitutional Court's jurisprudence}

There are not explicit references to 'constitutional tradition' in the Portuguese legal system, nor does it give it a specific legal significance. The Portuguese Constitution distinguishes between two kind of norms: principles and rules. ${ }^{73}$ Human dignity (article 1), equality (article 13), rule of law and separation and interdependence of powers (article 2) are principles. Right to life (article 24), freedom of expression and information (article 37 ), right to travel and to emigrate (article 44) or the right to vote (article 49) are rules.

\footnotetext{
${ }^{66}$ A. Ben-Bassat and M. Dahan, "Social rights in the constitution and in practice", Journal of Comparative Economics, 36 (1), 2008, pp. 103-119, J. Martinez Soria, "Das Recht auf Sicherung des Existenzminimums", Juristenzeitung, 13, 2005, pp. 647-655, and M. B. Vieira and F. C. da Silva, "Getting Rights Right: Explaining social rights constitutionalization in revolutionary Portugal", International Journal of Constitutional Law, 11 (4), 2013, pp. 898-922, pp. 898-899.

${ }^{67}$ C. S. Botelho, "Constitutional narcissism on the couch of psychoanalysis... cit., pp. 369-370.

${ }^{68}$ It has instead referred to the existence of a "multilevel constitutional system" and that article $8, \S 4$ urges obligations that emerge directly from EU law (PCC Ruling no. 575/2014, 15.08.2014, para. 25).

${ }^{69}$ PCC Ruling no. 141/2015, 25.02.2015, para. 7.

70 C. S. Botelho, "Is there a middle ground between constitutional patriotism and constitutional cosmopolitanism?... cit., pp. 447-448.

${ }^{71}$ A. M. G. Martins and M. P. Roque, "Judicial Dialogue in a Multilevel Constitutional Network - The role of the Portuguese Constitutional Court", Courts and Comparative Law (ed. M. Andenas \& D. Fairgrieve), Oxford Scholarship Online, 2015, pp. 309 ff.

7272 F. P. Coutinho and N. Piçarra, "Portugal: The Impact of European Integration and the Economic Crisis on the Identity of the Constitution", A. Albi and S. Bardutzky (eds.), National Constitutions in European and Global Governance: Democracy, Rights, the Rule of Law, 2019, pp. 591-639, p. 602.

73 C. S. Botelho, "O papel dos princípios na interpretação constitucional”, Estudos em Homenagem ao Conselheiro Presidente Rui Moura Ramos, Almedina, Coimbra, vol. I, 2016, pp. 59-86, pp. 75-84, and M. A. Vaz, Teoria da Constituição - O que é a Constituição, hoje?, Coimbra Editora, Coimbra, 2012, pp. 104111.
} 
Additionally, the cultural and axiological dimensions add societal values that reflect and influence the constitutional text. ${ }^{74}$ Values can be understood as "transcendent limits" to the constituent power and can deem a constitutional norm unconstitutional (unconstitutional constitutional norms). ${ }^{75}$ Some references are made to "values", such as "the preservation of cultural values and assets that are of historic or artistic interest (article 66, $\S 2, c)$ ); "respect for environmental values and assets" (article 66, $\S 2, g)$ ); "motherhood and fatherhood constitute eminent social values" (article 68, § 2); and "the law may provide for the participation of lay magistrates in judgements (...) that justify special consideration of the social values that have been infringed" (article 207, §2).

Portugal belongs to the civil law tradition. The legalist tradition does not give much room for custom. As Carlos Blanco de Morais refers, "the role of custom as an instrument of implicit alteration of constitutional norms is very modest" ${ }^{76}$ Furthermore, we can argue that, as the Portuguese Constitution is very detailed, customary constitutional law has remained underdeveloped.

Custom is not an immediate source of law. Still, doctrine recognizes the existence of custom secundum legem and prater legem, if acknowledged by the constitutional jurisdiction. ${ }^{77}$ Legal scholarship prefer to use the expression "conventions" (usos institucionais) to address constitutional praxis that somehow possess constitutional soft law status. ${ }^{78}$ One example is the constitutional praxis that has limited the power of the President of the Republic regarding the nomination of the Prime-Minister, on the grounds that the government needs parliamentary support in order to get its programme approved (articles 187, § 1, and 192 of the Constitution). ${ }^{79}$

\footnotetext{
${ }^{74}$ M. A. Vaz, Teoria da Constituição... cit., p. 114.

${ }^{75}$ For a general perspective on unconstitutional constitutional norms, see O. Bachof, Verfassungswidrige Verfassungsnormen?, J. C. B. Mohr, Tübingen, 1951 and Y. Roznai, Unconstitutional Constitutional Amendments - The Limits of Amendment Powers, Oxford University Press, Oxford, 2017.

${ }^{76}$ C. B. Morais, Curso de Direito Constitucional - Teoria da Constituição em Tempo de Crise do Estado Social, II, Coimbra Editora, Coimbra, 2014, p. 254.

${ }^{77}$ C. B. Morais, Curso de Direito Constitucional... cit., p. 254, and M. A. Vaz, Teoria da Constituição... cit., pp. 113-114.

${ }^{78}$ C. B. Morais, Curso de Direito Constitucional ... cit., pp. 254-255.

${ }^{79}$ C. S. Botelho, "Portugal: The State of Liberal Democracy", in R. Albert, D. Landau, P. Faraguna \& S. Drugda (Ed.), 2017 Global Review of Constitutional Law, I.CONnect and the Clough Center for the Study of Constitutional Democracy at Boston College, 2018, pp. 230-234: "In the 2015 legislative elections, the colligation PàF (Portugal à Frente) - which gathered the centre-right party PSD (Social Democratic Party) and the conservative CDS-PP (Popular Party) - won by 39\%. However, after being nominated by President Cavaco Silva as Government, the colligation PàF was not able to pass its programme within the Parliament. A motion of rejection of the Government's programme was approved by 123 votes, determining its fall (articles 194/4 and 195/1/d)). For that reason, this Government was the shortest one in the history of the Portuguese constitutional democracy, governing only for twenty-eight days. According to the Constitution, the President was doubly limited. In fact, due to him being in the last semester of his term of office, and to
} 
The Portuguese system draws a clear distinction between administrative and constitutional law, although mutual imbrication is inevitable. ${ }^{80}$ Portuguese scholars have imported Fritz Werner's assertion of administrative law as "materialized constitutional law" (konkretisiertes Verfassungsrecht ${ }^{81}$. In fact, Otto Mayer's maxim of the beginning of last century, which declared "constitutional law passes, administrative law remains" (Verfassungsrecht vergeht, Verwaltungsrecht besteht) was overtaken by the new demands of modern society. Currently and above the legality principle, the principle of constitutionality has become the gravitational center of an entire legal order. ${ }^{82}$ It is therefore common to refer to the "administrative constitution" (Werner), although regulation is gradually conquering more space. ${ }^{83}$

The concept of 'common constitutional traditions', endorsed in article 6, § 3 TUE, is translated by the PCC as "tradições constitucionais comuns aos Estados-Membros" (constitutional traditions that are common to Members States), thus suggesting the Europeanization of this subject: A common ground between different European legal orders.

the Parliament being in the first semester since its election (article 172/1), he was not able to dissolve the Parliament and call an early general election.

This constitutional impasse lead to a political crisis and the President only had three viable options: (i) maintain a caretaker Government, which was not the best solution, since the Government would have to "limit itself to undertaking the acts that are strictly necessary in order to ensure the management of public affairs" (article 185/6) and therefore, with a low political legitimacy, could not underplay innovative legislative acts; (ii) nominate a government of presidential initiative, in a boarder-based firm, with members of the three political parties that had signed the Memorandum of Understanding with "Troika". Nevertheless, due to the distressing political crisis, such composition would almost certainly fail again when submitting its programme to the Parliament; (iii) nominate a Government of the Socialist Party (which was the second most voted party), after two other left-wing parties - the Communists (PCP) and the Left Bloc (BE) - clarified that they would bestow their parliamentary support. The President opted for this last alternative, believing it could guarantee stability. For the first time since the establishment of democracy, PCP and BE supported the party in government."

${ }^{80}$ See J. Miranda, "Os parâmetros constitucionais da reforma do contencioso administrativo", Cadernos de Justiça Administrativa, 24, 2000, pp. 3-10, p. 3, J. J. G. Canotilho, Direito Constitucional e Teoria da Constituição, cit., p. 966, P. C. Rangel, Repensar o Poder Judicial - Fundamentos e Fragmentos, Universidade Católica, Porto, 2001, p. 184, and V. P. da Silva, O Contencioso Administrativo como Direito Constitucional Concretizado ou Ainda por Concretizar (?), Almedina, Coimbra, 1999, p. 5.

${ }^{81}$ Apud K. Schlaich and S. Korioth, Das Bundesverfassungsgericht - Stellung, Verfahren, Entscheidungen, Verlag C. H. Beck, München, 2004, p. 16. This assumption, however, does not mean that administrative law is a mere concretization of constitutional law, without its own scientific autonomy.

82 C. S. Botelho, A Tutela Directa dos Direitos Fundamentais - Avanços e Recuos na Dinâmica Garantística das Justiças Constitucional, Administrativa e Internacional, Almedina, Coimbra, 2010, p. 23. ${ }^{83}$ J. Robert, "Droit administratif et droit constitutionnel", Revue du Droit Public (et de la Science Politique en France et a l'étranger), 4, 1998, pp. 971-978, p. 971. 
The definition of the "constitutional alma mater" 84 or the "identity core" 85 of a national constitution is the responsibility of the constitutional jurisdiction of each state, ${ }^{86}$ provided that it respects EU law. ${ }^{87}$ A search into the database of the PCC revealed the following results:

(i) one entry for "identidade constitucional" (constitutional identity) ${ }^{88}$;

(ii) seven entries for "identidade nacional" (national identity), although filtered to five (as two of them referred to the pleadings), two citing article $4, \S 2$ TEU,${ }^{89}$ one referring to article $6, \S 3$ TEU, ${ }^{90}$ another citing a legal diploma, ${ }^{91}$ and yet another mentioning cultural national heritage ${ }^{92}$

(iii) Ten entries for "tradição constitucional" (constitutional tradition), although filtered to eight for the same reason mentioned above: three as obiter dicta ${ }^{93}$ and five referring to legacies of previous Portuguese constitutions ${ }^{94}$

(iv) Four entries filtered to three for "tradições constitucionais" (constitutional traditions): one referring to the constitutional experiences of other states ${ }^{95}$, and two citing article $6, \S 3$ TEU ${ }^{96}$;

(v) None for "tradição comum" (common tradition) nor for "tradições comuns" (common traditions);

(vi) Five references for "tradição nacional" (national tradition): one dissenting opinion $^{97}$ and four referring to a legal tradition ${ }^{98}$;

(vii) Zero entries for "tradições nacionais" (national traditions);

\footnotetext{
${ }^{84}$ C. S. Botelho, "Constitutional narcissism on the couch of psychoanalysis... cit., pp. 372-374.

${ }^{85}$ M. L. Duarte, "Sobre o caso Gauweiler... cit., p. 763.

${ }^{86} \mathrm{P}$.-E. Lehmann, Réflexions sur la nature de l'Union Européenne à partir du respect de l'identité nationale des États membres, Université de Lorraine, 2013, p. 6, available at: https://hal.univ-lorraine.fr/tel01750918/document

${ }^{87}$ F.-X. Millet, L'Union européenne et l'identité constitutionnelle des États membres, LGDJ, Paris, 2013,

${ }^{88}$ PCC Ruling no. 305/2011, 29.06.2011.

${ }^{89}$ PCC Rulings no. 575/2014, 14.08.2014, and no. 574/2014, 14.08.2014.

${ }^{90}$ PCC Ruling no. 345/02, 11.07.2002.

${ }^{91}$ PCC Ruling no. 54/99, 26.01.1999.

92 PCC Ruling no. 280/90, 23.10.1990.

${ }^{93}$ PCC Rulings no. 64/2005, 02.02.2005, no. 494/99, 05.08.1999, and no. 174/93, 17.02.1993.

94 PCC Rulings no. 267/88, 29.11.1988, no. 109/88, 01.06.1988, no. 157/85, 31.07.1985, no. 120/84, 05.12,1984, and no. 49/84, 06.06.1984.

95 PCC Ruling no. 296/2013, 28.05.2013.

${ }^{96}$ PCC Rulings no. 611/2013, 24.09.2013, and no. 224/2006, 23.03.2006.

${ }^{97}$ PCC Ruling 417/18, 09.08.2018.

98 PCC Rulings no. 48/99, 19.01.1999, no. 254/98, 05.03.1998, no. 121/97, 19.02.1997, and no. 31/84, 27.03.1984.
} 
(viii) One entry for "património constitucional" (constitutional heritage), mentioning the legal judge principle; ${ }^{99}$

(ix) And zero entries for "legado constitucional" (constitutional legacy).

\section{Distinctive traits of Portuguese constitutionalism:}

\subsection{A unique hybrid constitutional justice system $^{100}$}

The Portuguese constitutional review model is hybrid, as it shares characteristics of the monist/Kelsenian model as also traits of the diffused model of judicial review. The American influence is an indirect one. In fact, Article 63 of the first republican Portuguese Constitution (1911) was inspired in the Brazilian Constitution (1891), which in turn was influenced by the United States Constitution (1787).

In comparison with the Italian, German and Spanish systems of judicial review, the Portuguese system has some unique traits. ${ }^{101}$ If the first States opted for concentrated constitutional justice and to give incidental control mechanisms the form of preliminary review, the latter gives judicial review powers to ordinary courts as well. Accordingly, if an ordinary judge finds that the norm applicable to a case is unconstitutional, the judge does not suspend the process and questions the Constitutional Court. The Portuguese ordinary courts can dismiss the norm application in that concrete judicial process, since they are under the duty not to apply rules they consider unconstitutional (article 204). ${ }^{102}$ Despite having these powers, matters in the ordinary courts can be referred to a court outside the ordinary jurisdiction - a Constitutional Court.

Notwithstanding the appraisal of the original traits of the Portuguese constitutional justice model, the truth is that many scholars suggest improvements. One of the deficits

\footnotetext{
${ }^{99}$ PCC Ruling no. 667/99, 14.12.1999.

100 C. S. Botelho, "Is there a middle ground between constitutional patriotism and constitutional cosmopolitanism?... cit., pp. 426-427.

101 Vide, amongst many references, J. Miranda, "As instituições políticas portuguesas", La Constitución Portuguesa de 1976 - Un estudio académico treinta años después, 2006, pp. 35-ff, p. 41, J. de M. Alexandrino, "Il sistema portoghese dei diritti e delle libertà fondamentali: zone franche nella tutela giurisdizionale”, Diritto Pubblico Comparato ed Europeo, 2003, pp. 271-ff, p. 272, M. L. Amaral, "Problemas da Judicial Review em Portugal", cit., p. 82, and V. Moreira, "A "fiscalização concreta" no quadro do sistema misto de justiça constitucional", Boletim Comemorativo do $75 .^{\circ}$ Tomo do BFD, 2003, pp. 815-ff.

102 See J. J. G. Canotilho and V. Moreira, A Constituição da República Portuguesa Anotada, vol. II, Coimbra Editora, Coimbra, 2010, pp. 517-523.
} 
of protection is the absence of a constitutional complaint mechanism, similar to the Spanish "recurso de amparo constitucional" or the German "Verfassungsbeschwerde". 103

\subsection{The longest unamendable clause in the world ${ }^{104}$}

Unamendable clauses (also called entrenchment/eternity clauses) are armors against constitutional law's contingency and portrait a given constitutional identity. ${ }^{105}$ They impose substantial limits to constitutional change.

The Portuguese unamendable clause is so remarkable that it raises the pertinent question of its compatibility with a plural and democratic State. ${ }^{106}$ For the first time in Portuguese constitutional history, article 288 (former article 290) establishes several substantial limitations to the amendment power. ${ }^{107}$

The substantial limits to amendments are the following:

“a) National independence and unity of the state; $b$ ) The republican form of government; $c$ ) Separation between church and state; $d$ ) Citizens' rights, freedoms and guarantees; e) The rights of workers, works councils, and trade unions; $f$ ) The

103 A. Vitorino, "A justiça constitucional - Notas sobre o futuro (possível?) da justiça constitucional”, Revista do Ministério Público, VI, pp. 9-14, C. S. Botelho, A Tutela Directa dos Direitos Fundamentais, cit., pp. 167-284, and "Haja uma Nova Jurisdição Constitucional - Pela introdução de um mecanismo de acesso directo dos particulares ao Tribunal Constitucional”, Revista da Ordem dos Advogados, 70, 2011, pp. 591-623, J. Miranda, Ideias para uma revisão constitucional em 1996, Cosmos, Lisboa, 1996, p. 29, J. R. Novais, "Em Defesa do Recurso de Amparo Constitucional (ou uma Avaliação Crítica do Sistema Português de Fiscalização Concreta da Constitucionalidade)", in Themis, ano VI, 2005, pp. 91-117, J. J. G. Canotilho, Estudos Sobre Direitos Fundamentais, Coimbra Editora, Coimbra, 2004, p. 79, J. M. S. Correia and J. B. Gouveia, "Princípios constitucionais do acesso à justiça, da legalidade processual e do contraditório; junção de pareceres em processo civil; interpretação conforme à Constituição do artigo 525 . $^{\circ}$

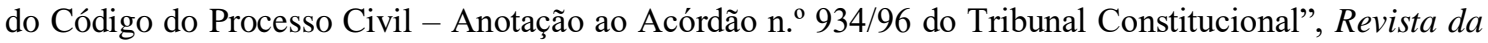
Ordem dos Advogados, 57, 1997, pp. 295-357, pp. 301-302, M. A. Vaz, A Responsabilidade Civil do Estado - Considerações breves sobre o seu estatuto constitucional, Universidade Católica Editora, Porto, 1995, p. 15, nt. 30 and p. 16, nt. 33, M. R. de Sousa and J. de M. Alexandrino, Constituição da República Portuguesa-Comentada, Livraria Petrony, Lisboa, 2000, p. 103, M. L. Amaral, "Queixas Constitucionais e Recursos de Constitucionalidade (Uma Lição de 'Direito Público Comparado')”, Estudos Comemorativos dos 10 Anos da Faculdade de Direito da Universidade Nova de Lisboa, vol. I, Almedina, 2008, pp. 473501, pp. 496-499, N. Piçarra, O Tribunal de Justiça das Comunidades Europeias como juiz legal e o processo do artigo $177 .^{\circ}$ do Tratado da CEE - As relações entre a ordem jurídica comunitária e as ordens jurídicas dos Estados-membros da perspectiva dos tribunais constitucionais, Livraria Petrony, Lisboa, 1991, pp. 95-96, P. Otero, Ensaio sobre o caso julgado inconstitucional, Lex, Lisboa, 1993, p. 121, and V. Moreira "Princípio da maioria e princípio da constitucionalidade: legitimidade e limites da justiça constitucional", Legitimidade e Legitimação da Justiça Constitucional - Colóquio no $10{ }^{\circ}$ Aniversário do Tribunal Constitucional, Coimbra Editora, Coimbra, 1995, pp. 177-198, p. 192.

104 I will follow very closely my considerations in "Constitutional narcissism on the couch of psychoanalysis... cit., pp. 363-366.

${ }^{105}$ R. Albert, 'Constitutional Handcuffs', Arizona State Law Journal, Vol. 42, 2010, pp. 663-715, p. 700.

106 See F. L. Pires, Teoria da Constituição de 1976 - A Transição Dualista, Coimbra, 1988, p. 161, and R. Medeiros, A Constituição Portuguesa num Contexto Global, cit., p. 213. Peter Suber, in F. Araújo, 'Limites à revisão constitucional - um paradoxo?', Polis - Revista de Estudos Políticos, 7-8, 1999, pp. 95-99, referred to this norm as "a distressing naivety" of the Portuguese constituent power.

107 In the Portuguese constitutional history, only the republican constitution of 1911 established an entrenchment clause, which was the "republican form of government". 
coexistence between the public, private, and cooperative, and social sectors of ownership of the means of production; $g$ ) The existence of economic plans, within the framework of a mixed economy; $h$ ) The appointment of the elected officeholders of the entities that exercise sovereignty, of the organs of the autonomous regions and of local government organs by universal, direct, secret and periodic suffrage, and the proportional representation system; i) Plural expression and political organisation, including political parties, and the right of democratic opposition; $j$ ) The separation and interdependence of the entities that exercise sovereignty; $l$ ) The subjection of legal norms to review of their positive constitutionality and of their unconstitutionality by omission; $m$ ) The independence of the courts; $n$ ) The autonomy of local authorities; $o$ ) The political and administrative autonomy of the Azores' and Madeira's archipelagos"108.

Material limits can be implicit as well. Scholars have identified some implicit limitations, such as: the protection of territorial integrity (inferred from the unity of the State) ${ }^{109}$, the principle of irresponsibility of judges (derived from the principle of judicial independence and impartiality), and the prohibition of lifelong mandates (resulting from the democratic principle). ${ }^{110}$

The current version of the Portuguese Constitution contains 14 clauses of entrenchment, as some were removed or altered in the constitutional amendment of 1989. Therefore, "it is quite clear that the unchangeable clause was indeed changed. The collapse of communism and the political changes of the 90s asked for a renewed understanding of what a constitution should be: not a government's programme, not a semantic constitution, but an open constitution. As the constitutional praxis did not take these limits into consideration, they became obsolete norms."

The Portuguese Constitution does not seem to allow a simultaneous double revision, which is the synchronized amendment of the entrenchment clause and of the

\footnotetext{
108 This provision was approved by a significant majority, since only 5 parliament members of the conservative CDS-PP (Popular Party) voted against it.

109 O. Doyle, "Constraints on Constitutional Amendment Powers", The Foundations and Traditions of Constitutional Amendment (eds. R. Albert, X. Contiades, \& A. Fotiadou), Portland, Hart Publishing, 2017, pp. 73-95, p. 94. Y. Roznai and S. Suteu, “The Eternal Territory? The Crimean Crisis and Ukraine's Territorial Integrity as an Unamendable Constitutional Principle", German Law Journal, 16, 2015, pp. 542580 , p. 573 , believe that the alteration of a polity such as territoriality should be done through existing constitutional processes.

110 J. E. M. Machado, "The Portuguese Constitution of 1976", Engineering Constitutional Change - A Comparative Perspective on Europe, Canada and USA (ed. X. Contiades), Routledge, 2013, pp. 273-298, p. 283.

111 C. S. Botelho, "Constitutional narcissism on the couch of psychoanalysis... cit., pp. 363-264. See R. Albert, "Constitutional Amendment by Constitutional Desuetude", American Journal of Comparative Law, 62 (3), 2014, pp. 641-686. Another interesting perspective is the idea of "constitutional atrophy". See A. Vermeule, "The Atrophy of Constitutional Powers", Oxford Journal of Legal Studies, 32 (3), pp. 421-444.
} 
principles and articles related to that limit. ${ }^{112}$ However, the 1989 amendment did operate a synchronized amendment, eliminating former paragraph $j$ ) from the substantial limits list. $^{113}$ Simultaneously, article 81 of the Constitution was modified regarding "nationalizations" and "rural estate property", while other significant changes were introduced in the economic Constitution, concerning the "structure of the means of production".

\subsection{The economic constitution}

One of the most interesting features of the Portuguese Constitution is the relevance given to economic, social and cultural rights. Notwithstanding the incompleteness of the sociological split between functional and aspirational conceptions of constitutionalism, the Portuguese constitution fits well in the latter. Aspirational constitutionalism embodies the following traits: a prolix and exhaustive constitutional text; a wide catalogue of fundamental rights; and the very generous granting of social constitutional rights, even beyond the budgetary possibilities of the State ${ }^{114}$. Such constitutional arsenal is sometimes difficult to interpret and to implement. Therefore, questions rise regarding the dilution of borders between judicial and legislative power. ${ }^{115}$

The wishful thinking of the Portuguese constitutional framers is well documented. Many foreign authors considered this baroque text an inconsistent compromise between liberalism and socialism, or a "project for building a future". ${ }^{116}$ Portuguese economic constitution was inspired in the Constitution of the Republic of Weimar (1919) and the philosophies of "economic democracy" (Wirtschaftsdemokratie) and "social market economy" (soziale Marktwirtschaft). ${ }^{117}$

\footnotetext{
${ }^{112}$ C. S. Botelho, "Constitutional narcissism on the couch of psychoanalysis... cit., p. 363.

${ }^{113}$ Paragraph $j$ ) stated "the participation of grass-roots popular committees in the local government". The former version of paragraph $f$ ) entrenched "the principle of collective appropriation of the means of production, of the soil, and of natural resources" and "the prohibition of monopolies and large rural estates" (currently paragraph $f$ ) has a softer tone: "the coexistence of the public, private and cooperative and social sectors of ownership of the means of production"). Former paragraph $g$ ) entrenched the "principle of democratic central planning of the economy" (now: "economic plans" "within the framework of a mixed economy").

${ }^{114}$ C. S. Botelho, Os direitos sociais em tempos de crise ... cit., pp. 167-164.

${ }^{115}$ C. S. Botelho, "Aspirational constitutionalism, social rights prolixity ... cit., pp. 76-84.

116 O. de Carvalho, "The Constitution of the Republic of Portugal and the ownership of the means of production", Boletim da Faculdade de Direito da Universidade de Coimbra, 1981, pp. 223-229, p. 223.

117 See A. Batista, "As constituições económicas portuguesa e espanhola em perspectiva comparada: transição democrática e abertura relativa dos sistemas económicos ibéricos", O Direito, IV, 2012, pp. 909950, and P. A. Pardal, "O acidental percurso da constituição económica portuguesa", Revista de Concorrência e Regulação, 22, 2015, pp. 17-53, pp. 20-21.
} 
One must highlight, though, that, during the monarchic constitutions $(1822,1826$, and 1838) and the first republican constitutional experience (1911) a kind of "implicit economic constitutionalism" occurred: minimum state and maximum individual freedoms (economic liberalism). ${ }^{118}$ The authoritarian Constitution of 1933 was the first Portuguese constitution ever to implement an economic and social order - corporatism being, thus, the first formal economic constitution. ${ }^{119}$

The current Portuguese Constitution (1976), implemented after the transition to democracy, tried to implement a socialist economic constitution, which gathered legal, philosophical and economic principles envisioned for transitioning to a classless society. ${ }^{120}$ Revolutionary socialism and collectivism meant economic change through: $(i)$ collective appropriation of the main means of production; (ii) democratic economic planning; (iii) and the exercise of democratic power by working people. ${ }^{121}$ The Constitution recognized three major sectors of ownership: the public sector (which should be the dominant one); the cooperative sector; and the private sector.

Constitutional amendments of 1982 and 1989 were of paramount importance, as they revisited the economic constitution, eliminated many of its norms, and neutralized the main socializing traits. ${ }^{122}$ Additionally, after the Portuguese adhesion to the (then) European Communities, in 1985, and the Maastricht Treaty, in 1992, the economic constitution shifted very clearly to a market economy and to a regulatory state. The current economic constitution (articles 80 to 107) is, beyond a doubt, surpassed by the European economic constitution. ${ }^{123}$

Hence, some doctrine considers that the Portuguese economic constitution needs further amendments which can truly reflect the European integration. ${ }^{124}$ More vehemently, Paulo Otero considers that the economic constitution should be fully interpreted in conformity with EU law, even if that means the "marginalization or

\footnotetext{
${ }^{118}$ M. A. Vaz, Direito Económico, Coimbra Editora, Coimbra, 4. a ed., 1998, pp. 51-52.

${ }^{119}$ P. A. Pardal, "O acidental percurso da constituição económica portuguesa”, cit., p. 25.

${ }^{120}$ The constitutional text had norms such as: "the Portuguese Republic is a Democratic State (...) with the goal of assuring the transition to socialism through the creation of conditions for the exercise of power by the working classes" (article 2); "the law can regulate that the expropriation of landowners, owners and entrepreneurs or shareholders does not give rise to any compensation" (article 82); "all nationalizations (...) are irreversible conquests of the working classes" (article 83).

${ }^{121}$ O. de Carvalho, "The Constitution of the Republic of Portugal... cit., p. 224.

${ }^{122}$ C. S. Botelho, "Aspirational constitutionalism, social rights prolixity and judicial activism... cit., p. 66.

${ }^{123}$ M. A. Vaz and M. F. Campos, "Anotação ao artigo 80. "”, Constituição Portuguesa Anotada (ed. J. Miranda \& R. Medeiros), vol. II, Universidade Católica Editora, Lisboa, 2018, pp. 13-27.

${ }^{124}$ C C. B. Morais, Curso de Direito Constitucional... cit., p. 260, and F. P. Coutinho and N. Piçarra, "Portugal: The Impact of European Integration... cit., p. 600.
} 
ignorance of constitutional provisions contrary or barely compatible with certain imperatives that stem from EU law." 125

\subsection{Perfectionism and prolixity of the fundamental rights catalogue}

Fundamental rights are codified in the Portuguese constitution "with a careful, quite perfectionist, systematization which can rarely be found in comparative constitutional law". ${ }^{126}$ The Fundamental rights catalogue consists of sixty-eight articles. With regard to liberty rights, if the Constitution bravely declares that they "bind private entities" (article 18, $\S 1$ ), it then paradoxically abandons them to the ordinary justice, as a constitutional complaint mechanism is not consecrated in the Constitution. ${ }^{127}$

As I mentioned above, the hope for continuous progress translated in the Portuguese constitution having one of the widest social rights catalogues in the world and probably the broadest in Europe.

For example, article 66 consecrates the right to environment and quality of life with such density that it places the Portuguese Constitution as a pioneer in environmental protection through fundamental rights' constitutionalization. Echoing this concern, the Portuguese constitution influenced the Spanish, Brazilian and Mozambican ones. ${ }^{128}$ Besides this, the detailed list of rights, freedoms and guarantees regarding the criminal justice system (articles 27 to 32) is quite unusual from a comparative constitutional law perspective. $^{129}$

In consonance with the "clear-cut division of the time," 130 the Portuguese Constitution rifts fundamental rights in two categories: $(i)$ rights, liberties and freedoms

\footnotetext{
${ }^{125}$ P. Otero, Legalidade e Administração Pública: o sentido da vinculação administrativa à juridicidade, Almedina, Coimbra, 2003, p. 549. In a similar sense, V. Moreira, “A CRP e a União Europeia”, cit., p. 905. 126 J. R. Novais, Direitos Fundamentais e Justiça Constitucional em Estado de Direito Democrático, Coimbra Editora, Coimbra, 2012, p. 240.

${ }^{127}$ Idem, p. 289.

${ }^{128}$ M. da G. Garcia and G. Matias, "Anotação ao artigo 66." ${ }^{\circ}$, Constituição Portuguesa Anotada (ed. J. Miranda and R. Medeiros), Coimbra Editora, Coimbra, 2010, pp. 1340-1355.

${ }^{129}$ F. P. Coutinho and N. Piçarra, "Portugal: The Impact of European Integration... cit., pp. 606-607.

130 "This systematic option is the reality of most international legislation approved after the Second World War. In 1966, the International Covenant on Civil and Political Rights (ICCPR) and the International Covenant on Economic, Social and Cultural Rights (ICESCR) were approved. (...) In an international regional dimension, there is also a clear division between the European Convention on Human Rights (1950) and the European Social Charter (1961). The latter has a very inferior enforceability level when compared to the ECHR." (C. S. Botelho, "Aspirational constitutionalism, social rights prolixity... cit., pp. 68-69). See also S. Deakin and J. Browne, "Social Rights and Market Order: Adapting the Capability Approach", Economic and Social Rights under the EU Charter of Fundamental Rights - A Legal Perspective (ed. T. K. Hervey \& J. Kenner), Hart Publishing, 2003, pp. 27-43, p. 38.
} 
(Title II - articles 24 to 57); and (ii) social, economic and cultural rights (Title II - articles 58 to 79$)$.

This division would not be relevant if the constitutional framer did not consecrate a special regime for rights, liberties and freedoms (herein liberty rights). Indeed, the Portuguese Constitution reserves a special regime to liberty rights. ${ }^{131}$ This raises the question of social rights' regime. Is it the same as liberty rights? The Portuguese doctrine is highly divided in this matter. ${ }^{132}$ I stand for a renewed understanding of social rights, grounded in material indivisibility and structural interaction between liberty rights and social rights. ${ }^{133}$

Article 17 consecrates an open-clause on fundamental rights concreteness, which, in turn, allows immediate applicability of rights that have a similar/analogous nature to liberty rights. ${ }^{134}$ This permits bridging liberty rights and social rights, upgrading social rights sometimes more evanescent structure. From a comparative constitutional law perspective, article 17 is an innovative norm. ${ }^{135}$

\footnotetext{
${ }^{131}$ They have immediate applicability, bind public and private entities and benefit from rigorous limitations to their restriction (article 18, clearly inspired by article 1/3 from the German Grundgesetz); the right to "resist any order that infringes their rights, freedoms or guarantees and, when it is not possible to resort to the public authorities, to use force to repel any aggression" (article 21); furthermore, unless it also authorizes the Government to do so, the Assembly of the Republic (Parliament) has exclusive competence to legislate on liberty rights $(b)$ n. $^{\circ} 1$ article 165 ) - Although some social rights also benefit from this partially exclusive legislative competence from the Assembly of the Republic, given $f$ ), $g$ ) and $h$ ) no 1 article 165 (bases of social security, national health service, nature/ecologic balance/cultural heritage and the e general regime governing rural and urban rentals); finally, amongst several material limits on constitutional amendment, "constitutional revision laws must respect citizens' rights, freedoms and guarantees" ( $d$ ) article 288).

132 There are "three main narratives that were built around this inquiry: (i) Some authors defend a rigid bifurcation between liberty and social rights and even argue for an ontological superiority of liberty rights when compared with social rights. Far from conferring independent constitutional rights, social rights would be principles orientating the state's action. (ii) On the other extreme of this discussion, others defend regime parity between both rights and refuse any distinction. Then, all infra constitutional legislation on social rights is a constitutional continuum. (iii) The majority of the doctrine supports an intermediate thesis - more or less equidistant - which states that there is no substantial hierarchy between rights (are indivisible, unitary and non-hierarchical), just a formal distinction, based either on different regimes, on State's duties or even on the determinability of the right's content." (C. S. Botelho, "Aspirational constitutionalism, social rights prolixity... cit., pp. 72-73)

${ }_{133}$ C. S. Botelho, Os direitos sociais em tempos de crise ... cit., pp. 313-321.

${ }^{134}$ Article 17 states the following: "The regime governing rights, freedoms and guarantees applies to those set out in Title II and to fundamental rights of an analogous nature."

${ }^{135}$ C. B. Morais, Curso de Direito Constitucional ... cit., p. 573, C. S. Botelho, Os direitos sociais em tempos de crise ... cit., p. 122, and pp. 305-311, J. Miranda e R. Medeiros, "Anotação ao artigo 17. .", Constituição Portuguesa Anotada, vol. I, cit., pp. 302-309, J. J. G. Canotilho and V. Moreira, A Constituição da República Portuguesa Anotada, vol. I, Coimbra Editora, Coimbra, 2017, pp. 370-378, and M. A. Vaz, Teoria da Constituição... cit., p. 160.
} 
Social rights enforcement was unsettled during Troika's intervention in Portugal (2011-2014). ${ }^{136}$ The Memorandum of Understanding signed between the Monetary International Fund, the European Commission and the European Central Bank compelled the Portuguese legislators to a very strict austerity programme. Consequently, several measures which distressed Portuguese societal tissue were implemented: public sector wage cuts, tax increases, flexibilization of dismissal rules, pensions cuts and other welfare benefits, privatization of public utilities, increased working hours (for civil servants and equivalent), convergence of pension systems (public and private sectors), amongst other measures. ${ }^{137}$

In the beginning of the application of the Memorandum of Understanding, the PCC was criticized for its favor legislatoris jurisprudence. ${ }^{138}$ Yet, deference towards the legislator started to decrease by 2012, as the argument of a "transitional and exceptional circumstance" could not be sustained for a long period of time. ${ }^{139}$ In 2013/2014, the PCC considered the argument of the exceptional economic-financial conjuncture as surpassed. ${ }^{140}$

PCC's crisis jurisprudence received unprecedented attention and international coverage. ${ }^{141}$ If some acclaimed the Court's unwillingness to convey with social state

\footnotetext{
${ }^{136}$ More generally, see M. Kumm, Taking 'the dark side' seriously: Constitutionalism and the question of constitutional progress. Or: Why is it fitting to have the 2016 ICON-S conference in Berlin, 13 (4) I.CON 779, 777-785 (2015).

${ }^{137}$ C. S. Botelho, "Aspirational constitutionalism, social rights prolixity... cit., p. 79.

${ }^{138}$ During 2010 and 2011, PPC judgments seemed to adhere to the crisis' rhetoric and to refrain from interfering with budgetary impositions and international commitments. See PCC ruling number 399/2010, from October $27^{\text {th }}$ (retroactive personal income tax pensions); and number 396/2011, from September $21^{\text {th }}$, (public sector wage cuts).

${ }^{139}$ Therefore, its tolerance to the crisis argument would be inversely proportional to the duration of the crisis. PCC ruling number 353/2012, from July $5^{\text {th }}$ (suspension of the Christmas-month (13th month) and holiday-month (14th month) payments of annual salaries, both for persons who receive salaries from public entities and for persons who receive retirement pensions from the public social security system). This judgment was highly controversial, as the PCC limited the retroactive effects of the declaration of unconstitutionally on the grounds of "exceptionally important public interest" (article 282/4). In fact, the PCC suspended its decision's effects in order to permit the full execution of the state budget (which had already been executed for half a year).

PCC ruling number 187/2013, from April $5^{\text {th }}$ (review of the constitutionality of norms contained in the State Budget Law for 2013).

${ }^{140}$ PCC ruling number 862/2013, from December $19^{\text {th }}$ (Civil Service Law - Statute governing the Retirement of the Public Sector Staff); number 413/2014, from May $30^{\text {th }}$ (review of the constitutionality of norms contained in the State Budget Law for 2014 - the PCC declared the unconstitutionality of the majority of the measures syndicated); number 575/2014, from August $14^{\text {th }}$ (proposed creation of an additional tax - "Sustainability Contribution" - updating pensions in the public social protection system); number $3 / 2016$, from January $13^{\text {th }}$ (elimination of the lifetime annuity for former political officials, declared unconstitutional on the grounds of the violation of the principle of the protection of trust).

${ }^{141}$ C. Kilpatrick, "Constitutions, social rights and sovereign debt states in Europe: a challenging new area of constitutional inquiry", European University Institute 13-14 (2015), and J. C. da Costa, "Tribunal Constitucional e debate público", 40 Anos de Políticas de Justiça em Portugal, Almedina, 2016, pp. 113141.
} 
downsizing, others criticized it for obstructing free-market economy, and even suggested the "dissolution of the Constitutional Court as an independent court."142

For current purposes, we can discuss if the 'constitutional identity' of some EU Member States (such as Greece, Spain, Portugal or Italy) was respected by the European entities during their international bailouts. To Francisco Balaguer Callejón, the "economic interpretation of the Constitution that was imposed all over Europe, and to which a constitutional interpretation of the crisis shall have been opposed to", did not respect the pluralist democracy principle. ${ }^{143}$ It is also important to mention that the PCC was not some sort of "Don Quixote' fighting the windmills of austerity", as it "made every effort to internalize the European and international obligations of the Portuguese state." 144

\subsection{The insular autonomic regime}

Portugal was always a unitary state. With the transition to democracy, after several decades of dictatorship, the democratic principle called for some decentralization of the majority deliberation: the insular autonomic regime. ${ }^{145}$ Nevertheless and contrary to other constitutional experiences (such as Spain), autonomy is not a right per se but a "constitutional status". How many regions there may be and which competences they may have is not open to discussion. It is the Constitution that defines which regions there are - in the Portuguese case, the Azores and Madeira archipelagos - and the extension of their competences. ${ }^{146}$

According to article 6 of the Portuguese Constitution, Portugal is a partial and homogeneous regional unitary state. ${ }^{147}$ In fact, there is a single Kompetenz-Kompetenz

\footnotetext{
${ }^{142}$ See generally, A. Dimopoulos, "PIGS and Pearls: State of Economic Emergency, Right to Resistance and Constitutional Review in the Context of the Eurozone Crisis", Vienna Journal on International Constitutional Law, 2013, 7 (4), pp. 501-520, C. S. Botelho, "Aspirational constitutionalism, social rights prolixity... cit., pp. 78-81, L. Gordillo Pérez, "Derechos Sociales y Austeridad”, Lex Social, 2014, pp. 3456, N. Rodean, "Social rights in our backyard: 'Social Europe' between standardization and economic crisis across the continent", European Social Charter and the challenges of the XXI Century, Edizioni Scientifiche Italiane, 2014, pp. 23-49, pp. 41-42, and S. Corado, N. Garoupa \& P. Magalhães, Judicial Behaviour Under Austerity - An Empirical Analysis of Behavioral Changes in the Portuguese Constitutional Court, 20022016, JLC 26 (2017), at 10.

${ }^{143}$ F. Balaguer Callejón, "El final de una época dorada, cit., p. 101. Similarly, C. S. Botelho, Os direitos sociais em tempos de crise... cit., pp. 487-488.

${ }^{144}$ F. P. Coutinho and N. Piçarra, "Portugal: The Impact of European Integration... cit., pp. 618-619.

${ }^{145}$ M. L. Amaral, A Forma da República - Uma introdução ao estudo do direito constitucional, Coimbra Editora, Coimbra, 2005, pp. 367-378.

${ }^{146}$ Idem, p. 371.

147 See J. Miranda, “Anotação ao artigo 6. "”, Constituição Portuguesa Anotada, vol. I, cit., pp. 138-147, and J. J. G. Canotilho \& V. Moreira, Constituição da República Portuguesa Anotada, cit., pp. 642-651.
} 
power, but with two autonomous regions with limited legislative, executive and international powers. ${ }^{148}$ Along with Continental Portugal, they form the whole of the Portuguese Republic. Why these regions and not others?

They were established due to their insularity and historical autonomic aspirations. Article $225, \S 1$, very clearly establishes that "the grounds for the specific political and administrative regime of the Azores and Madeira archipelagos are their geographic, economic, social and cultural characteristics and the island populations' historic aspirations to autonomy." 149 In a similar tone, article 229, § 1 asserts that "in cooperation with the self-government organs, the entities that exercise sovereignty shall ensure the economic and social development of the autonomous regions, with a particular view to the correction of the inequalities derived from insularity." 150

Therefore, article 81, e), states that "in the economic and social field the state is under a priority duty to promote the correction of the inequalities derived from the autonomous regions' insular nature and encourage those regions' progressive integration into broader economic areas within a national or international framework."151

Partial regional autonomy (self-government) is therefore one of the identifying traits of the Portuguese constitutional system. This is so vital, that regional autonomy is an "eternity clause", refrained from the amendment process (article 288, o) of the Constitution).

Article 225, $\S 3$ of the Constitution of the Portuguese Republic establishes that the regional political and administrative autonomy does not affect the "integrity of the sovereignty of the state and must be exercised within the overall framework of this Constitution". Besides the Constitution, the Political and Administrative Statutes of each of the Autonomous Region, regulate the exercise of self-government. Addressing "disputes over the autonomy", the regional self-governance regime enhanced through the various amendments to the Portuguese Constitution.

A singular trait of the Portuguese Constitution is that, as far as political associations and parties are concerned, "no party may be formed with a name or manifesto objectives that show it has a regional nature or scope" (article 51, § 4). The prohibition

\footnotetext{
${ }^{148}$ See F. U. Calvão, M. F. Campos and C. S. Botelho, Introdução ao Direito Público, Almedina, Coimbra, 2016, p. 155, and R. Lanceiro, "The international powers of the Portuguese autonomous regions of Azores and Madeira", Revista da Faculdade de Direito da Universidade de Lisboa, 51, 2010, pp. 293-320.

${ }^{149}$ J. J. G. Canotilho and V. Moreira, Constituição da República Portuguesa Anotada, vol. II, cit., pp. 641644.

${ }^{150}$ Idem, ibidem, pp. 688-692.

${ }^{151}$ Idem, Constituição da República Portuguesa Anotada, I, cit., pp. 964-974.
} 
of regional parties has been criticized by some, as it restricts freedom of association, contributes to low turnout rates in the autonomous regions, and does not respect the autonomy of the regions.

It is relevant to mention that this prohibition, consecrated in 1976, was thought to be short-term. In fact, during the Portuguese transition to democracy, there was come concern about separatist tendencies in the autonomous regions of Azores and Madeira. Although these fears were unfounded, the prohibition of regional parties was even reinforced, as it moved from the organizational part to the fundamental rights catalogue. $^{152}$

\subsection{Flexibility of the legal definition of the right to strike}

The right to strike is, under the Portuguese Constitution, a fundamental right (placed in the rights, liberties and guarantees catalogue) and immediately applicable to public and private entities (article 18). According to article 57, §2, "workers have the competence to define the scope of the interests that are to be defended by a strike and the law may not limit that scope."153

The lack of a legal conceptualization of the right to strike does not allow a distinction between conducts that can be considered strikes and other behaviours that should be excluded from constitutional protection. ${ }^{154}$ If some scholars blame the constitutional prohibition of legal limitation of "the scope of the interests that are to be defended by a strike" for the absence of a legal concept of strike, ${ }^{155}$ others argue that this legal flexibility should be restricted by a legal definition which takes into consideration the sociological perspective of the strike. ${ }^{156}$ Nevertheless, article $57, \S 2$ displays "a rare case of express prohibition of fundamental rights' restrictions". ${ }^{157}$

Additionally, article 57, $\S 4$, explicitly prohibits employers' lockouts. A lockout is a crime, punishable with imprisonment up to two years and may result in a fine applied to the employer (articles 544 and 545 of the Portuguese Labour Code).

\footnotetext{
152 J. Miranda, "Anotação ao artigo 51.", Constituição Portuguesa Anotada, vol. I, cit., pp. 1008-1021, p. 1016, and J. J. G. Canotilho \& V. Moreira, Constituição da República Portuguesa Anotada, cit., p. 658. ${ }^{153}$ See J. J. G. Canotilho \& V. Moreira, Constituição da República Portuguesa Anotada, cit., pp. 750-760, and R. Medeiros, "Anotação ao artigo 57.", Constituição Portuguesa Anotada, vol. I, cit., pp. 1124-1135. ${ }^{154}$ J. J. G. Canotilho e J. Leite, "Ser ou não ser uma greve (a propósito da chamada 'greve self-service')", Questões Laborais, 13, 1999, pp. 3-44, p. 15.

${ }_{155}$ J. J. Abrantes, "A greve no novo Código do Trabalho", A Reforma do Código do Trabalho, Coimbra Editora, Coimbra, 2014, pp. 651-661, p. 74, and P. R. Martinez, Direito do Trabalho, Almedina, Coimbra, 7. ${ }^{\mathrm{a}}$ ed., 2015, p. 1194.

156 B. Xavier, 1984, p. 62.

157 J. J. G. Canotilho \& V. Moreira, Constituição da República Portuguesa Anotada, cit., p. 756.
} 
The Portuguese prohibition of lockout is so wide that the Portuguese state had to make reservations to the European Social Charter: Portugal formally declared that the obligations entered under article $6, \S 4$ shall in no way invalidate the prohibition of lockouts as enshrined in the Portuguese Constitution.

Another interesting aspect is that the constitutional prohibition of lockout was subject to the PCC appreciation, with the argument that it could be a case of unconstitutional constitutional norm. In Ruling 480/89, without formally answering the vexata quaestio of whether unconstitutional constitutional norms were a valid constitutional theory, the PCC decided that the prohibition of lockout did not violate the equality principle. ${ }^{158}$ In fact, it considered that equality should not be refrained in a formal dimension, but share a material dimension as well. The material dimension of the equality principle allows to treat differently what is different and equally what is equal. In this sense, the Court considered that the employer and the employee were not in an equal position, and therefore the law could treat them in a different way. If the PCC had decided otherwise, probably it would have to deem that constitutional norm unconstitutional.

\subsection{Prohibition of military/ paramilitary, racist or fascists organizations - Limits to pluralism?}

Regarding the freedom of organization, the triad violent, racist and fascist is constitutionally forbidden. Article $46^{\circ}$, $\S 4$ states that "armed associations, military, militarized or paramilitary-type associations and organisations that are racist or display a fascist ideology are not permitted."159 On the one hand, the Portuguese Constitution prohibits parties which resort to or encourage violence (armed associations, military, militarized or paramilitary-type), even if it they are not subversive or racist per se. Such exclusion flows from the rule of law, democratic principle and the unicity of the armed forces (article 275, §2). ${ }^{160}$

On the other hand, racist organizations are prohibited, as they violate the human dignity principle (equal social dignity). There are a few historical examples, such as the apartheid, some colonialist organizations, holocaust, genocide, skinheads' movements,

\footnotetext{
${ }^{158}$ From 13.07.1989.

159 See J. Miranda, “Anotação ao artigo 46.", Constituição Portuguesa Anotada, vol. I, cit., pp. 952-960, and J. J. G. Canotilho \& V. Moreira, Constituição da República Portuguesa Anotada, cit., pp. 642-651.

${ }^{160}$ According to Article 275, no. 2, "the Armed Forces shall be composed exclusively of Portuguese citizens and shall have a single organizational structure for the whole of Portuguese territory". See J. J. G. Canotilho and V. Moreira, Constituição da República Portuguesa Anotada, vol. II, cit., pp. 868-872.
} 
etc.). ${ }^{161}$ The reference to "racist" organizations was not in the original version of the Portuguese Constitution, being added later through the constitutional amendment of 1997. Additionally, the prohibition of fascism is a legacy from the Portuguese authoritarian regime of 1933-1974. The Preamble of the Portuguese Constitution very clearly attests that "on the 25th of April 1974 the Armed Forces Movement crowned the long resistance and reflected the deepest feelings of the Portuguese people by overthrowing the fascist regime." Some doctrine considers such prohibition an unconstitutional constitutional norm or a "material constitutional self-rupture", since it violates the principles of equality and pluralism. ${ }^{162}$ Is it justified to prohibit only extreme-radical-right and not also extremeradical-left organizations, such as some communist organizations which historically were also accountable for massive deaths and human rights violations?

The Constitutional Court is responsible for declaring, according to the terms and for the purposes of Law no. 64/78, dated 6 October, that an organization has adopted a fascist ideology and for decreeing its respective abolition" (article 10 of the Law of the Portuguese Constitutional Court). ${ }^{163}$ Regarding the Parliament, "members of the Assembly of the Republic shall lose their seat in the event that (...) they are convicted of participating in organizations that are racist or display a fascist ideology" (article 160, § $1, \mathrm{~d})$ ).

\subsection{A sui generis system of government and the government's power to legislate in all the subjects that are not reserved to the parliament}

After several decades of parliamentary instability (during the First Republic, 1910-1926) and dictatorship (1926-1933 and 1933-1974), the Portuguese Constitution of 1976 sought to establish a system of government that would emphasize checks and balances between the main political organs: President, government and parliament. ${ }^{164}$

The Portuguese political system is mostly characterized as semi-presidential, since the President of the Republic is directly elected and the government (and Prime-

\footnotetext{
${ }^{161}$ J. J. G. Canotilho \& V. Moreira, Constituição da República Portuguesa Anotada, cit., p. 648.

162 J. Miranda, "Anotação ao artigo 46. "., cit., pp. 959-960. Therefore, the Author recommends that this article be interpreted restrictively (according to Article 18, no. 2): the prohibition only affects the political organization and not freedom of speech; by "fascist ideology" one should interpret an ideology similar to the Portuguese pre-revolution period or to the Italian fascist experience, which influenced the Portuguese one. In agreement with this last assertion, see J. J. G. Canotilho \& V. Moreira, Constituição da República Portuguesa Anotada, cit., p. 648.

${ }^{163}$ Law no. 28/82, of 15 November, modified by Law no. 143/85, of 26 November, Law no. 85/89, of 7 September, Law no. 88/95, of 1 September, Law no. 13-A/98, of 26 February, and Organic Law no. 1/2001). ${ }^{164}$ V. Canas, “The Semi-Presidential System”, ZaöRV, 64, 2004, pp. 095-124, p. 95.
} 
Minister) are politically responsible to the legislature. ${ }^{165}$ Others, though, prefer the designation of "premier-presidential system", ${ }^{66}$ or even "parliamentary system."167

The Portuguese system was influenced by the French semi-presidentialism, and the rationalized parliamentarism of the Weimar Republic. ${ }^{168}$ The parliamentary traits are the following: the government as a political autonomous organ (article 182); the government is responsible to the parliament, either through the consideration of the government's programme (article 192), the request for confidence motion (article 193) or the motion of no confidence (article 194); and the ministerial counter-signature (article 140). The characteristics of the presidential regime are three: direct election of the President (article 120), presidential veto (article 136), and presidential powers of political indirizzo (such as article 133,d)). Last but not least, the rationalized parliamentary traits relate to the government's double responsibility to the parliament and to the President (articles 190 and 191), and the dissolution of the parliament by the President (article 172).

Notwithstanding external influences, the Portuguese Constitution reveals some unique traits. The government is not necessarily formed by the party that wins the legislative elections. Article 187, $\S 1$ of the Constitution affirms that the "the President of the Republic appoints the Prime Minister after consulting the parties with seats in the Assembly of the Republic and in the light of the electoral results", but he needs parliamentary support in order to get his programme expressly or implicitly approved (article 192). ${ }^{169}$

Even if the nomination of the current Portuguese government - a contraption (geringonça) formed by the Socialist Party (PS), the Communist Party (PCE) and the farleft party Left Bloc (BE) - was consistent with the Constitution, it generated some criticism amongst PSD and CDS-PP, the elections winning parties. ${ }^{170}$ However, while the assertion that the party/colligation with the highest percentage of votes wins the elections

\footnotetext{
165 G. Passarelli, "The government in two semi-presidential systems: France and Portugal in a comparative perspective", French Politics, 8 (4), 2010, pp. 402-428, O. A. Neto and M. C. Lobo, "Portugal's semipresidentialism (re)considered: An assessment of the President's role in the policy process, 1976-2006", Portugal in the Twenty-First Century: Politics, Society and Economics, 2012, p. 49, and V. Canas, "The Semi-Presidential System", ZaöRV, 64, 2004, pp. 095-124, p. 116.

${ }^{166}$ R. Elgie, Semi-presidentialism - Sub-Types and Democratic Performance, Oxford University Press, Oxford, 2011, pp. 29, 122, 132-43.

167 J. J. G. Canotilho and V. Moreira, Constituição da República Portuguesa Anotada, vol. II, cit., p. 19.

168 M. A. Vaz, R. Carvalho, C. S. Botelho and A. T. Ribeiro, Direito Constitucional - O sistema constitucional português, Universidade Católica Editora, Porto, 2015, pp. 30-37.

169 C. S. Botelho, "Portugal: The State of Liberal Democracy", cit., pp. 230-234.

170 In my opinion, behind this political distress was the fact that there was a kind of "gentlemen's agreement" according to which the political alliances in the Parliament would be made known to the electorate a priori and not a posteriori.
} 
is correct, it does not mean that it is entitled to form government. One thing is to win the legislative elections, another one is to form government.

Another interesting trait of the Portuguese political system is that the President cannot dismiss the government at his discretion, but only "when it becomes necessary to do so in order to ensure the normal operation of the democratic institutions and after first consulting the Council of State" (article 195, § 2). The Council of State is "the political organ that advises the President of the Republic" (article 141).

In continuity with the previous Constitution of 1933, the current Constitution grants the government a wide range of legislative powers: (i) exclusive powers "to legislate on matters that concern his own organization and modus operandi" (article 198, $\S 2$ ); (ii) independent powers to legislate "on matters that do not fall within the exclusive competence of the Assembly of the Republic" (article 198, § 1, a)), and therefore law (parliament's legislation) and decree-law (government's legislation) share the exact same legal status, being mutually revocable (lex posteriori derrogat lex anteriori); (iii) and dependent powers to legislate on matters of the competence of the Parliament (article $165)$, "subject to authorization" (article 198, § 1,b)) or to "make executive laws that develop the principles or the general bases of the legal regimes contained in laws that limit themselves to those principles or general bases" (article 198, § 1,c)). ${ }^{171}$

In Europe, parliaments are decreasing their political and legislative strength in favour of governments, which possess indirect democratic legitimacy. ${ }^{172}$ The length of the Portuguese government's independent/concurring powers are unique in a comparative constitutional law perspective. ${ }^{173}$ Although the parliament is the most important legislative organ - since qualitatively the utmost relevant subjects belong to its area of legislative competence (articles 161, 164 and 165) $)^{174}$ and it has primacy even above

\footnotetext{
171 J. J. G. Canotilho and V. Moreira, Constituição da República Portuguesa Anotada, vol. II, cit., pp. 477483.

172 C. B. Morais, O Sistema Político no Contexto da Erosão da Democracia Representativa, Almedina, Coimbra, 2017, p. 722, and P. Otero, Direito Constitucional Português, I, Almedina, Coimbra, 2010, p. 209.

173 C. B. Morais, O Sistema Político... cit., pp. 719-723, and J. Miranda and J. P. da Silva, “Anotação ao artigo 161."”, Constituição Portuguesa Anotada, vol. II, cit., pp. 502-516, p. 506.

174 See J. Miranda and C. S. Botelho, "Anotações aos artigos 164. ${ }^{\circ}$ e 165. ${ }^{\circ}$, , Constituição Portuguesa Anotada, vol. II, cit., pp. 527-555.
} 
governmental legislation (article 169) ${ }^{175}$ - the truth is that quantitatively, the government legislates much more. ${ }^{176}$ In fact, the government produces $80 \%$ of the legislation. ${ }^{177}$

Some argue that the extent of governmental competences is too generous and should be shortened through constitutional amendment. ${ }^{178}$ To counterbalance the government's (possibly) excessive legislative powers, the President plays a relevant role. Unlike the veto of parliament legislation, which can be surpassed, ${ }^{179}$ the veto of government legislation is definitive (article 136, § 4). ${ }^{180}$

Therefore, the Portuguese President is more than a mere "pouvoir neutre" (Benjamin Constant) which preserves national stability, guarantees checks and balances between the organs of the state and guards the Constitution of 1976. Willingly, the President can play a more interventive political role.

\subsection{Restrictiveness of referenda}

National referenda were introduced, in a very restrictive way, by the second constitutional amendment of 1989. 1997's constitutional amendment implemented a specific referendum for the creation of administrative regions (article 256) and a regional referendum (article 232, § 2). In practice, Portugal only had three national referenda (1998 - abortion; 1998 - regionalization; and 2007 - abortion) since the transition to democracy.

There are several concrete principles guiding referenda, such as: the existence of a relevant national, regional or local interest at stake (articles 115, 33 and 232, § 2); unicity of the referendum subject (article $115, \S 6$ ); yes or no questions (article 115, no

\footnotetext{
${ }^{175}$ According to article 169, no 1: "1. Save for those passed in the exercise of the Government's exclusive legislative competence, executive laws may, upon a motion made by ten Members of the Assembly of the Republic within the thirty days following their publication (...) be subjected to consideration by the Assembly of the Republic with a view to causing them to cease to be in force or amending them."

${ }^{176}$ M. A. Vaz, R. Carvalho, C. S. Botelho and A. T. Ribeiro, Direito Constitucional, cit., pp. 52-58.

177 C. B. de Morais, As Leis Reforçadas - As leis reforçadas pelo procedimento no âmbito dos critérios estruturantes das relações entre actos legislativos, Coimbra, 1998, p. 193, J. Valle, A participação do Governo no exercício da função legislativa, Coimbra, 2004, p. 294, and J. Miranda and J. P. da Silva, "Anotação ao artigo 161. o", Constituição Portuguesa Anotada, vol. II, cit., pp. 502-516, pp. 505-506.

${ }^{178}$ J. de M. Alexandrino, "A preponderância do Governo no exercício da função legislativa", Legislação (Cadernos do INA), 2009, pp. 99-108.

${ }_{179}$ According to article 136, § 2: "If the Assembly of the Republic confirms its vote by an absolute majority of all the Members of the Assembly of the Republic in full exercise of their office, the President of the Republic must enact the legislative act within a time limit of eight days counting from its receipt."

180 Although a government with a parliamentary majority can always surpass the presidential veto, through article 197, § 1, d): "In the exercise of its political functions the Government has the competences to present and submit government bills and draft resolutions to the Assembly of the Republic". Then, the government can "copy-paste" its law-decree into a draft resolution to the parliament. If the parliament approves the draft and the subsequent law, the President can veto that law, but the parliament is able to surpass the veto by an absolute majority (article 136, § 2).
} 
6); and the existence of a binding effect only "when the number of voters exceeds half the number of registered electors" (article 115, § 11). ${ }^{181}$

A unique trait of the Portuguese system is that referenda are not for the immediate popular approval or disapproval, but to decide whether that legal diploma (law, convention, local decree, etc.) should be approved or rejected by the pertinent legislative organs. The idea was to avoid populist manipulations in favour of representative democracy, although this argument is weak given the restrictiveness and requirements of referenda design in the Portuguese system. ${ }^{182}$

A quorum of participation was introduced by 1997's constitutional amendment. Accordingly, it is required that the number of voters exceeds "half the number of registered electors" (article 115, § 11) for the referendum to have binding effect. The ratio legis was to avoid binding referendum results over relevant national questions approved by an electoral minority. ${ }^{183}$

However, this rule has been heavily criticized by some Portuguese doctrine, since it has the pernicious effect of encouraging abstention. ${ }^{184}$ If turnout is not over $50 \%$, then the referendum is nonbinding and merely consultative. This rule could make sense if our Constitution allowed referenda over constitutional issues. ${ }^{185}$ Yet, such referenda are expressly forbidden in Portugal(article 115, § 4, a)), as well in other states such as Greece and Luxembourg.

\subsection{Universal Declaration of Human Rights as a constitutional continuum}

Article 16, $\S 2$, regarding the scope and interpretation of fundamental rights, states that "the constitutional norms concerning fundamental rights must be interpreted and completed in harmony with the Universal Declaration of Human Rights." The question, therefore, is the following: Is the Universal Declaration of Human Rights (UDHR) a constitutional continuum or a mere interpretative instrument?

${ }^{181}$ J. Miranda, "O referendo e o plebiscito: a experiência portuguesa", Cuestiones Constitucionales, 19, 2008, pp. 149-171, p. 158.

${ }^{182}$ Idem, p. 159.

183 J. J. G. Canotilho and V. Moreira, Constituição da República Portuguesa Anotada, vol. II, Coimbra Editora, Coimbra, 2010, p. 101.

184 J. J. G. Canotilho and V. Moreira, Constituição da República Portuguesa Anotada, vol. II, cit., p. 101, J. Miranda, "O referendo e o plebiscito: a experiência portuguesa", Cuestiones Constitucionales, 19, 2008, pp. 149-171, p. 160, P. Magalhães, "A necessária eliminação do n. ${ }^{\circ} 11$ do artigo 115.", A Constituição Revista, (eds. J.A. Tavares, M. P. Maduro, N. Garoupa e P. Magalhães), FFMS, Lisboa, 2011, pp. 103-105, and Raquel Brízida Castro, "Como salvar a Democracia dos seus 'novos donos", Público, 04.06.2019, https://www.publico.pt/2019/06/04/politica/opiniao/salvar-democracia-novos-donos-1875166

$\overline{185}$ J. Miranda, "O referendo e o plebiscito: a experiência portuguesa", cit., p. 160. 
To some doctrine, article $16, \S 2$ is an interpretative norm, as it refers to an exterior parameter of interpretation: The UDHR. ${ }^{186}$ In this sense, the Portuguese Constitution should be interpreted in consonance with the Declaration. An example could be article 2 of the UDHR, which, when interpreted toe to toe with the Portuguese prohibition of discrimination (article 13, $§ 2$ of the Constitution ${ }^{187}$ ) clarifies that this prohibition is not exhaustive, but merely suggestive. Therefore, we can argue that the Constitution also prohibits discriminating people with disabilities. ${ }^{188}$

Other scholars, though, enlarge the above interpretation and argue that Article 16, $\S 2$ proceeds to the formal reception of the UDHR as a material extension of the written constitution. The UDHR thus has a supra-constitutional value. ${ }^{189}$ Concretely, it expands the fundamental rights catalogue (articles 24 to 79) and other fundamental rights consecrated elsewhere - in ordinary laws or in international norms - derived from the "open clause" in matters of fundamental rights (article 16, § 1). ${ }^{190}$ Accordingly, and as the Portuguese Constitution lacks a general permission of fundamental rights' restriction, article $29, \S 2$ of the UDHR could be immediately applicable as a constitutional norm for restriction. ${ }^{191}$

This doctrinal approach is criticized by authors that highlight its inconsistency with article $18, \S 2$ of the Portuguese Constitution, which limits fundamental rights' restrictions "in cases expressly provided for in the Constitution". ${ }^{192}$ Furthermore, human rights law instruments should never be interpreted in a way that diminishes human rights protection (article 53 of the Charter of Fundamental Rights of the European Union). ${ }^{193}$

\footnotetext{
${ }^{186}$ J. J. G. Canotilho and V. Moreira, Constituição da República Portuguesa Anotada, vol. I, cit., p. 367. 187 Article 13, § 2: "No one may be privileged, favoured, prejudiced, deprived of any right or exempted from any duty for reasons of ancestry, sex, race, language, territory of origin, religion, political or ideological beliefs, education, economic situation, social circumstances or sexual orientation."

188 C. S. Botelho, "A indiferença à diferença", Observador, 17/04/2018, available at: https://observador.pt/opiniao/a-indiferenca-a-diferenca/

${ }^{189}$ J. Miranda, “Anotação ao artigo 16. ${ }^{\text {", }}$ Constituição Portuguesa Anotada, vol. I, cit., pp. 289-301, p. 290.

${ }^{190}$ Article 16, no. 1, states that: "The fundamental rights enshrined in the Constitution shall not exclude any others set out in applicable international laws and legal rules." About the Portuguese "open clause", see A. M. G. Martins and M. P. Roque, "Universality and Binding Effect of Human Rights from a Portuguese Perspective", The Universalism of Human Rights (ed. R. Arnold), Springer, Heidelberg, 2013, pp. 297-324, p. 309.

191 Article 29, § 2 foresees the following: "In the exercise of their rights and freedoms, everyone shall be subject only to such limitations as are determined by law solely for the purpose of securing due recognition and respect for the rights and freedoms of others and of meeting the just requirements of morality, public order and the general welfare in a democratic society."

192 J. J. G. Canotilho and V. Moreira, Constituição da República Portuguesa Anotada, vol. I, cit., pp. 367369.

193 Which states that: "Nothing in this Charter shall be interpreted as restricting or adversely affecting human rights and fundamental freedoms as recognised, in their respective fields of application, by Union
} 


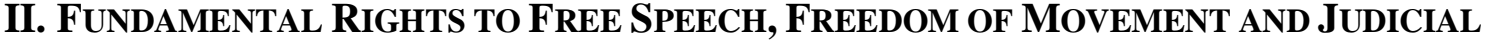 INDEPENDENCE}

\section{Free speech}

\subsection{Constitutional standards of scrutiny for free speech}

Article 37 of the Portuguese Constitution is a cluster-right, which grants freedom of expression and information. If we consider freedom of expression, we must associate it with human dignity (article 1) and the right to the development of personality (article $26, \S 1) .{ }^{194}$ Freedom of expression is also implied in freedom of conscience and religion (article 41), freedom of cultural creation (article 42), and freedom to learn and to teach (article 43), and is a prerequisite of access to law (article 20, $\S 1$ ), the right to demonstrate (article $45, \S 2$ ), or freedom to choose a profession (article 47). ${ }^{195}$

It is also relevant to mention that free speech (article 37) and freedom of association (article 46) are constitutionally separate rights. Commercial speech is not an autonomous category, such as in the United States. As freedom of expression and information are granted jointly in the Portuguese Constitution, types of speech/information that are ruled by law are the following: Law of Advertising and advertisement posting and registration; ${ }^{196}$ Television Law; ${ }^{197}$ Journalist's Status; ${ }^{198}$ Press Law; ${ }^{199}$ and Radio Law. ${ }^{200}$

José de Melo Alexandrino distinguishes four types of limits to freedom of expression: ${ }^{201}$

(i) immediate limits to freedom of expression: the Portuguese Constitution only contemplates one limit, which is that "everyone has the right to freely express and divulge their thoughts in words, images or by any other

\footnotetext{
law and international law and by international agreements to which the Union, the Community or all the Member States are party, including the European Convention for the Protection of Human Rights and Fundamental Freedoms, and by the Member States' constitutions."

${ }^{194}$ J. E. M. Machado, Liberdade de Expressão - Dimensões constitucionais da esfera pública no sistema social, Coimbra Editora, Coimbra, 2002, pp. 372.

195 J. Miranda, Manual de Direito Constitucional, IV, p. 453.

${ }^{196}$ Law no. 97/88, 17.08.1988.

${ }^{197}$ Law no. 27/2007, 30.07.2007.

${ }^{198}$ Law no. 1/99, 13.01.1999.

${ }^{199}$ Law no. 2/99, 13.01.1999.

${ }^{200}$ Law no. 4/2001, 23.02.2001.

${ }^{201}$ J. de M. Alexandrino, “Anotação ao artigo 37.”", Constituição Portuguesa Anotada, vol. I, cit., pp. 844859, pp. 850-851.
} 
means" (article 37, $\S 1$ ), therefore plagiarism is not protected by freedom of speech;

(ii) special limitations to some constitutional dimensions of freedom of speech, such as article 270 (restrictions on the exercise of rights by fulltime military personnel and militarized agents on active service and agents of the security services and forces); ${ }^{202}$

(iii) exceptional legal limitations resulting from a proportionality analysis (article 18, § 2 and 3) in order to balance freedom of expression with other fundamental rights or values, such as dignity, morals, privacy, image, and rule of law - we can exemplify with the criminal norms that punish defamation, insult ${ }^{203}$, deprivation of privacy, incitement to war and violence; 204

(iv) real conflict between freedom of speech and other fundamental rights in a given situation, which should be addressed through "practical reconciliation" (praktische Konkordanz). ${ }^{205}$

Notwithstanding the prohibition of censorship (article 37, § 2), "prevention of abuse of freedom of expression can be licit either through limited and exceptional criminal protection, or through disciplinary or administrative sanctions (article $37, \S$ $3)$ ". ${ }^{206}$ Article $37, \S 1$ very clearly asserts that "everyone has the right to freely express and divulge their thoughts in words, images or by any other means (...) without hindrance or discrimination." This means that, apart from the "cases expressly provided for in the Constitution" (article 18, § 2), all equally benefit from freedom of speech, without discrimination. $^{207}$

PCC jurisprudence lacks leading cases regarding the place and meaning of freedom of speech in the Portuguese constitutional context. ${ }^{208}$ However, it is relevant to

\footnotetext{
${ }^{202}$ Article 270 states that "strictly to the extent required by the specific demands of the respective functions, the law may establish restrictions on the exercise of the rights of expression, meeting, demonstration, association and collective petition by full-time military personnel and militarized agents on active service and agents of the security services and forces, and on their legal capacity to stand for election. In the case of the security forces, even when their right to form trade unions is recognized, the law may preclude the right to strike." See PCC ruling no. 384/03, 15.07.2003.

${ }^{203}$ See PCC ruling no. 345/2017, 28.06.2017.

${ }^{204}$ Articles 180, 181, 192, 297, 298 and 326 of the Portuguese Penal Code. See PCC ruling no. 605/07, 11.12.2007.

205 See PCC ruling no. 407/07, 11.07.2007.

206 See PCC ruling no. 292/2008, 29.05.2008.

${ }^{207}$ J. J. G. Canotilho and V. Moreira, Constituição da República Portuguesa Anotada, vol. I, cit., p. 573.

${ }^{208}$ J. de M. Alexandrino, "Anotação ao artigo 37.", Constituição Portuguesa Anotada, vol. I, cit., pp. 844859 , p. 857.
} 
mention that the Portuguese State has been recurrently condemned by the European Court of Human Rights for limiting free speech. ${ }^{209}$

There are several examples concerning judiciary acting and free speech, but I will focus on one case. José Manuel Fernandes, a well-known Portuguese journalist and editor, was found guilty of defamation by the Portuguese courts and condemned to pay $€ 60,000$ for an editorial article he wrote in 2006.

In the article, entitled "The strategy of the spider", Fernandes gave his opinion on the election of Justice Noronha Nascimento to the post of President of the Supreme Court of Justice and its significance, from his point of view, for the judiciary and the country. Fernandes considered Justice Noronha Nascimento the personification of the "dark side" of the Portuguese justice system, and wrote that he "has been weaving a web of connections of back-scratching, of favours and undertakings (there is an even worse word but I will avoid it)" and "presented himself to voters - that is to say, to his peers, and those whom he helped to promote to a position from which one day they would be able to elect him".

The ECHR ruled that "there is no doubt that this issue was a matter of legitimate public interest. (...) (Q)uestions concerning the functioning of the justice system, an institution that is essential for any democratic society, relate to a matter of public interest (...) In the instant case, these questions also relate to those who are elected to represent the various institutions within the judiciary. The first applicant's article therefore concerned a sphere in which restrictions on freedom of expression are to be strictly interpreted." 210

The Court reinforced that "members of the judiciary acting in an official capacity may be subject to wider limits of acceptable criticism than ordinary citizens (...) the President of the Supreme Court of Justice cannot be considered to be in the same position as any other judge: on the one hand, he is also the President of the HCJ; on the other hand, as the President of the Supreme Court of Justice he is the fourth-highest-ranking figure of State with a sit on the Council of State. The exercise of these roles is not part of adjudication. Thus, his ability to defend himself in public is wider than those of judges who exercise purely judicial acts." 211

\footnotetext{
${ }^{209}$ See ECHR cases Pais de Lima v. Portugal, no. 70465/12, 12.02.2019, Tavares de Almeida Fernandes and Almeida Fernandes v. Portugal, no. 31566/13, 17.01.2017, Sousa Goucha v. Portugal, no. 70434/12, 22.03.2016, and Gouveia Gomes Fernandes and Freitas e Costa v. Portugal, no. 1529/08, 29.03.2011.

${ }^{210}$ Para. 62, ECHR case of Tavares de Almeida Fernandes and Almeida Fernandes v. Portugal, cit.

211 Para. 63.
} 
In concrete, the ECHR decided "that the impugned statements do not concern the way in which Judge N.N. exercised his functions as judge nor his ability to deliver a judgment or his conduct in that respect. They concerned Judge N.N.'s career within the judiciary and were therefore connected to the functions that he had exercised until then, namely as leader of the trade union association of judges and Vice-President of the HCJ. The Court notes in this regard that the first applicant's remarks reflected the opinion that Judge N.N. owed his electoral success to actions he had pursued during his career and, in particular, the fact that he was an example of conservatism and corporatism, remarks which the domestic courts considered as being within the limits of criticism". ${ }^{212}$

The Court then considered "that the expressions used by the first applicant had a sufficiently close connection with material which had been previously published in the media about Judge N.N. and that he drew his opinion from that material and from conversations he had with different people from the judiciary (...) In this regard, although the first applicant's allegations may be critical and harsh, they remain within the limits of freedom of opinion". 213

In conclusion, the Court observed "that the domestic courts did not sufficiently explain how the first applicant had gone beyond his right to criticism and why his right to express his opinion should have been limited." ${ }^{214}$ Additionally, the Court reiterated that "under the Convention, an award of damages for defamation must bear a reasonable relationship of proportionality to the injury to reputation suffered". ${ }^{215}$

In sum, the Court considered "that the domestic courts have exceeded the margin of appreciation afforded to them regarding limitations on debates of public interest and that there is no reasonable relationship of proportionality between, on the one hand, the restriction on the first applicant's right to freedom of expression and, secondly, the legitimate aim pursued"216, and condemn the Portuguese State for a violation of article 10 of the Convention. ${ }^{217}$

More recently, just some weeks ago, in the case of Antunes Emídio and Soares Gomes da Cruz v. Portugal (concerning polemic articles published in newspapers by the first applicant, a journalist and the second, a doctor), the ECHR condemned the

\footnotetext{
212 Para. 67.

213 Para. 71.

214 Para. 75.

215 Para. 77.

216 Para. 81.

217 Para. 82.
} 
Portuguese State for violating article 10 of the Convention. ${ }^{218}$ Accordingly, the Court ruled that "the domestic courts have exceeded the margin of appreciation afforded to them regarding limitations on debates on matters of public interest and that there is no reasonable relationship of proportionality between the restriction on the (...) applicant's right to freedom of expression and the legitimate aim pursued. The balancing exercise had not been undertaken by the national authorities in full conformity with the criteria laid down in the Court's case-law, and, in any event (...) there are strong reasons to substitute the Court's view for that of the domestic courts." 219

\subsection{Interplay between free speech and crimes of opinion, display of religious} symbols, blasphemy, hate speech, holocaust denial, and burning of political symbols.

The Constitution also prohibits crimes of opinion, even when the opinions are linked with unconstitutional ideologies (such as racist or fascist). ${ }^{220}$ What the Constitution forbids are "armed associations, military, militarized or paramilitary-type associations and organizations that are racist or display a fascist ideology", not the ideas themselves (article 46, § 4).

From 1822 to 1911, Portugal was a constitutional monarchy with Catholicism as state religion. ${ }^{221}$ The Constitutional Charter of 1826 foresaw that "no one might be persecuted on grounds of religion, once it respects that of the state and does not offend public morality" (article 145, § 4). The republican Constitution of 1911 and the undemocratic Constitution of 1933 had similar (although lightened) formulas. ${ }^{222}$

On the contrary, the Constitution of 1976 consecrates "the separation between church and state" as an eternity clause. ${ }^{223}$ Differently than the previous Portuguese constitutions (except the Constitution of 1911) and the constitutions of Italy, Spain and Poland, the current constitutional text has zero references to the Catholic Church. ${ }^{224}$

\footnotetext{
218 Applications no. 75637/13 and 8114/14, 24.09.2019.

219 Par. 65.

${ }^{220}$ J. J. G. Canotilho and V. Moreira, Constituição da República Portuguesa Anotada, vol. I, cit., p. 575.

${ }^{221}$ J. de S. e Brito, "Portugal", [national report to] Religion and Discrimination Law in the European Union (ed. Mark Hill), European Consortium for Church and State Research, Trier, Institute for European Constitutional Law, 2012, pp. 271-280, p. 271, and P. P. Adragão, A Liberdade Religiosa e o Estado, Almedina, Coimbra, 2002, pp. 279-306.

222 P. P. Adragão, A Liberdade Religiosa e o Estado, cit., pp. 318-360.

223 Article 288, c). See M. B. Lopes, "A Liberdade religiosa em Portugal, a(s) Constituição(ções) e o Tribunal Constitucional", Estudos em Homenagem ao Conselheiro Presidente Rui Moura Ramos, Almedina, Coimbra, 2016, pp. 299-361.

${ }^{224}$ J. Miranda and P. G. Marques, "Anotação ao artigo 41", Constituição Portuguesa Anotada, vol. I, cit., pp. 890-921, p. 918.
} 
The Constitution consecrates a specific non-discrimination clause regarding religion: "No one shall be privileged or favoured, or discriminated against, or deprived of any right or exempted from any duty, by reason of their (...) religion" (Article 13, no. 2). This clause must be read in connection with article 41, §2: "No one shall be persecuted or deprived of rights or exempted from civil responsibilities or duties by reason of their convictions or religious observance."

Article $41, \S 4$ is clear when recognizing that "churches and other religious communities are separate from the state and are free to organize themselves and to exercise their functions and form of worship." Article 2, $\S 2$ of the Religious Freedom Law imposes that "the state shall not discriminate any church or religious community in relation to others." 225 The new concordat between Portugal and the Holy See (2004) was a step towards that compromise. ${ }^{226}$

Portugal has a model of "cooperative separation between political power and religious phenomenon." ${ }^{227}$ Hence, the Constitution rules that the state should be guided by religious neutrality. However, it is relevant to highlight that state's neutrality does not equal to simply ignoring the religious phenomenon, insofar as religion plays a relevant role in the fields of solidarity, social inclusion and schooling. ${ }^{228}$ With a sociological argumentation, the PCC has decided that while "separation between church and state involve religious neutrality of the state", it no longer involves "the obliviousness of the religious fact as a social fact." 229

There are several references to this idea of non-interference, such as in the media (article 41, $\S 5$ : "Freedom is guaranteed to each denomination to teach its religion and to use its own media to carry out pertinent activities"), in public education and culture development (article 43, § 2: "The state shall not plan education and cultural development in accordance with any philosophical, aesthetic, political, ideological or religious rules", and article 43, § 3: "Public education shall be nondenominational"), in the establishment

\footnotetext{
225 Law no. 16/2001, 22.06.2001.

226 Signed on $18^{\text {th }}$ May 2004, and which substituted the Concordat of 1940. See R. M. Ramos, "A Concordata de 2004 e o Direito Internacional Privado Português", Revista de Legislação e Jurisprudência, no. 3938, 2006, p. 277.

227 J. B. Gouveia, Religious Liberty and Rule of Law in Constitutional State: the Portuguese Experience, available at: http://www.clr.mj.pt/sections/agenda/representacao-da-clr-no/representacao-da-clrno/downloadFile/file/Religious_Liberty_and_Rule_of_Law_-

the_portuguese_experience.pdf?nocache $=1268737957.04$, and J. Miranda and P. G. Marques, “Anotação ao artigo 41”, Constituição Portuguesa Anotada, vol. I, cit., pp. 890-921, p. 912.

${ }^{228}$ J. Miranda and P. G. Marques, "Anotação ao artigo 41", Constituição Portuguesa Anotada, vol. I, cit., pp. 890-921, p. 912.

${ }^{229}$ PCC Ruling no. 423/87, 27.10.1987.
} 
of political parties (article 51, $3: 3$. Without prejudice to the philosophy or ideology that underlies their manifestoes, political parties may not employ names that contain expressions which are directly related to any religion or church, or emblems that can be confused with national or religious symbols.”).

Conscientious objection is granted in article 41, § 6 and it is intrinsically connected to the right to personal integrity (article $25, \S 1$ ). In this sense, conscientious objection does not pertain exclusively to religious sensitivities, but also to other conscience reasons, such as moral and philosophical ones. ${ }^{230}$ However, the Constitution clearly refers this subject to the infraconstitutional legislation. One example is the conscientious objection regarding abortion. ${ }^{231}$

Portugal has no legislation that prohibits the wearing of religious clothing or symbols neither in public employment, nor in private employment. If approved, such legislation would probably be deemed unconstitutional, although a proportionality analysis could lead the PCC to decide otherwise (v.g., if it has provocative intentions or if it is so severe that it offends human dignity). ${ }^{232}$ Furthermore, there is no significant case law regarding the wearing of religious clothing or symbols. ${ }^{233}$

And what about religious symbols (v.g., crucifixes) that are displayed in some public buildings - such as schools that function in old buildings from the last century? According to the Constitution and to the infraconstitutional legislation, they should not be displayed, although some exceptions might be tolerable in historical buildings or regions with steeped cultural tradition. ${ }^{234}$

On the other hand, Portugal does not oblige pupils to attend classes in religious education. In its Ruling 423/87, the PCC decided that "the Constitution prohibits the organization of state education along religious lines, unwarranted distinctions between the churches and followers of different religions and the operation of state schools as agencies of religious education. However, the Constitution does not prohibit, or even

\footnotetext{
${ }^{230}$ J. Miranda and P. G. Marques, "Anotação ao artigo 41", Constituição Portuguesa Anotada, vol. I, cit., pp. 890-921, pp. 920-921, and J. J. G. Canotilho and V. Moreira, Constituição da República Portuguesa Anotada, vol. I, cit., p. 616.

${ }^{231}$ Article 6 of Law no. 16/2007, 17.04.2007.

232 J. J. G. Canotilho and V. Moreira, Constituição da República Portuguesa Anotada, vol. I, cit., p. 617.

${ }^{233}$ See E. Howard, Religious clothing and symbols in employment A legal analysis of the situation in the EU Member States, European Commission, 2017, available at: https://ec.europa.eu/newsroom/just/itemdetail.cfm?item_id=608849

${ }^{234}$ J. Miranda and P. G. Marques, "Anotação ao artigo 41", Constituição Portuguesa Anotada, vol. I, cit., pp. 890-921, p. 913. See also P. P. Adragão, "Crucifixos e Minaretes: a Religião no Espaço Público", Revista de Direito Público, 3, 2010, pp. 201-210.
} 
prevent, the state from allowing the various churches to give religious instruction in state schools, provided that they are treated equally."235

Blasphemy (speaking sacrilegiously about God or sacred things) is not expressly punishable by law and pertains to the area of constitutionally protected speech. Nevertheless, there are some "blasphemy-like provisions" on the Portuguese Penal $\operatorname{Code}^{236}$. Article $251 \S 1$ states that "a person who in public offends another person or mocks them on the ground of belief or religious practice, in a way likely to disturb public peace, shall be punished with imprisonment up to one year or a fine up to 120 days." Article 252 foresees that "anyone who, by means of violence or significant threat, prevents or disrupts the legitimate exercise of religious worship or publicly vilifies the religious act or mocks it shall be punished with imprisonment up to one year or a fine up to 120 days."

We can conclude that, while blasphemy per se is not criminalized, some sort of "outrage to religious feelings" might be punishable. Still, it is not the disrespectful speech that is criminalized, but deliberate offence to religious liberty and public peace. ${ }^{237}$

Holocaust denial is protected speech in some states (United States), while criminalized in others (Germany). The German Basic Law "was intended as an unwavering repudiation of the country's Nazi past, thus fostering a constitutional identity that strongly encourages full integration of German Jews within the post-war German polity." 238

In Portugal, holocaust denial is not a crime itself, but there can be criminalization through the prohibition of incitement to hatred. Article 236 of the Portuguese Penal Code rules that "anyone who, publicly and repeatedly, incites hatred against a people with the intention of triggering a war, is punished with imprisonment from 6 months to 3 years". Additionally, article $240, \S 2$, b) foresees that "anyone who, in a public meeting, in writing intended for disclosure or through any means of social communication defames or injures a person or group of persons on account of their race, colour, ethnic or national origin or religion, including denial of war crimes or peace and humanity; with the intention of

\footnotetext{
235 Cited above. See also PCC Ruling no. 578/2014, 28.08.2014.

${ }^{236}$ M. H. QC and R. Sandberg, "The Right to Blaspheme", Blasphemy and Freedom of Expression Comparative, Theoretical and Historical Reflections after the Charlie Hebdo Massacre (ed. J. Temperman and A. Koltay), Cambridge University Press, 2017, pp. 114-136, p. 118.

${ }^{237}$ J. de S. e Brito, "Religion and Criminal Law in Portugal", Religion and Criminal Law. Religion et Droit Pénal (eds. M. Kotiranta \& N. Doe), Leuven, Peeters, 2013, pp. 215-223, and N. Doe, Law and Religion in Europe - A Comparative Introduction, Oxford University Press, 2011, pp. 65-78.

${ }^{238}$ M. Rosenfeld, "Constitutional Identity", cit., p. 774.
} 
inciting racial or religious discrimination or encouraging it, shall be punished with imprisonment from 6 months to 5 years."

Burning the national flag is not covered by freedom of speech. In fact, the national flag is a symbol of Portugal's sovereignty. According to article 11, § 1, "The National Flag, which is the symbol of the sovereignty of the Republic and of Portugal's independence, unity and integrity, is that adopted by the Republic formed by the Revolution of the 5th of October 1910".

It is true that the protection of the dignity of national symbols is not absolute and must be compromised with other constitutional values, such as freedom of speech, religious freedom and freedom of cultural creation. ${ }^{239}$ If some doctrine alerts that active manifestations of commitment to the national flag might be arguable (such as the mandatory participation in public acts of patriotism), a passive or non-aggressive fidelity to the national symbol is a civic and legal duty. ${ }^{240}$

Therefore, both the Portuguese Penal Code and the Military Justice Code 241 prohibit burning the flag. Article 332, $\S 1$ of the Penal Code states that: "Anyone who publicly, by words, gestures or dissemination of writing, or by other means of communication with the public, shall violate the Republic, national flag or anthem, arms or emblems of Portuguese sovereignty, or disrespect them, shall be punished with imprisonment up to 2 years or with a fine of up to 240 days." Specifically related to the military forces, article 102 of the Military Justice Code asserts the following: "The military person who publicly, by words, gestures or by dissemination of writings or by other means of communication with the public, insults the national flag, banner or national anthem, or lacks them respect, is punished: a) In time of war, with the penalty of 1 to 4 years of imprisonment; b) In peacetime, with a sentence of 1 month to 2 years in prison."

Additionally, article 7, § 2, a) of the Code of Publicity affirms: "Advertising shall be prohibited if: (a) Institutions, national or religious symbols or historical characters are deprecated". ${ }^{242}$, and article $17, \S 4$ foresees that: "it is forbidden to associate advertising

\footnotetext{
239 See J. Miranda, “Anotação ao artigo 11. ’”, Constituição Portuguesa Anotada, vol. I, cit., pp. 199-206, p. 202.

${ }^{240}$ A. de Araújo, “A Nação e os seus símbolos (Breves comentários ao artigo 11. a Constituição", Revista O Direito, 133, 2001, pp. 197 ff, p. 223.

${ }^{241}$ Law no. 100/2003, 15.11.2003.

${ }^{242}$ Law no. 330/90, 23.10.1990.
} 
of alcoholic beverages with national symbols, enshrined in Article 11 of the Constitution of the Portuguese Republic."

To some scholars, the ratio legis of this restrictive legislation is not patriotism or the advocacy of a collective sense of belonging, but the preservation of public peace. ${ }^{243}$

In respect to foreign flags or political flags, we did not find similar legislation. Here, freedom of speech and freedom of cultural creation should play a significant role. However, it would not be admissible to burn a flag that belongs to another person or to public entities. In that situation, we should apply the general civil law rules on the illegality of destroying the property of others.

\subsection{Free speech and new technologies}

New technologies are a challenge in modern times. The new EU Regulation has been wildly discussed, both with enthusiasm and scepticism. ${ }^{244}$ How can the current digital era of over-sharing be compatible with privacy? ${ }^{245}$ How to draw a line between the "optimism of freedom of expression" and the "dark side of Internet's freedom", which seems to feed the hate speech and discrimination $?^{246}$ Is there a right to be forgotten?

There are substantial differences in the way freedom of speech and privacy are perceived on both sides of the Atlantic: The United States of America and Western Europe. For example, as regards the "right to be forgotten" - anchored on human dignity, personal identity, development of personality, honour, good name and reputation, image, and privacy - I have identified a crescendo of protection depending on the jurisdiction that applies it: the US Supreme Court (minimalism); the European Court of Human Rights (compromise) and the ECJ (maximalism). ${ }^{247}$

In Portugal, article 35 protects the use of information technology. In particular, article $35, \S 1$ grants "every citizen (...) the right of access to all computerized data that concern them, which they may require to be corrected and updated, and the right to be

\footnotetext{
${ }^{243}$ J. Raposo, “O crime de 'ultraje aos símbolos nacionais' nos direitos português e norte-americano. Uma análise comparativa sobre as questões do bem jurídico tutelado e da legitimidade constitucional da intervenção penal", Estudos em Homenagem ao Conselheiro José Manuel Cardoso da Costa, Coimbra Editora, Coimbra, 2003, pp. 795-833, p. 824.

${ }^{244}$ Regulation (EU) 2016/679 of the European Parliament and of the Council, of 27 April 2016, on the protection of natural persons with regard to the processing of personal data and on the free movement of such data, and repealing Directive 95/46/EC (General Data Protection Regulation).

${ }^{245}$ C. S. Botelho, "Novo ou velho direito?... cit., p. 51.

246 A. Sajó e C. Ryan, "Judicial reasoning and new technologies: framing, newness, fundamental rights and the internet", The Internet and Constitutional Law - The protection of fundamental rights and constitutional adjudication in Europe (ed. O. Pollicino and G. Romeo), Routledge, 2016, pp. 3-25, p. 4.

${ }^{247}$ C. S. Botelho, "Novo ou velho direito?... cit., pp. 67-69.
} 
informed of the purpose for which they are intended, as laid down by law." Article $35, \S$ 3 asserts that "information technology may not be used to treat data concerning philosophical or political convictions, party or trade union affiliations, religious faith, private life or ethnic origins, except with the express consent of the data subject, or with an authorization provided for by law and with guarantees of non-discrimination, or for the purpose of processing statistical data that are not individually identifiable."248

Private and public interests in personal data motivated the Portuguese legislator to create the Portuguese Data Protection Authority (CNPD), an independent body which supervises and monitors compliance with the laws and regulations in the area of personal data protection. ${ }^{249}$ Its previous consultation on legal provisions relating to the processing of personal data is mandatory.

"In October 2015, the CNPD pronounced itself against parliamentary legislation (Decree no. 426/XII) that allowed intelligence officers from the Security Information Service (SIS) and the Strategic and Defence Information Service (SIED) to access traffic, localization and other electronic communications-related data, for purposes of prevention of phenomena such as terrorism, espionage, sabotage, and highly organised crime, as long as certain conditions (necessity, appropriateness, and proportionality) were respected. ${ }^{250}$

The legislative goal was not to access the content of communications (written or voice) but to obtain authorisation to demand the metadata (data about data) from the entities that treat data, concurring the conditions under which communications took place (location and traffic).

Two months later, and following the request of prior control from the former President of the Republic Aníbal Cavaco Silva, the PPC took the view that the legislation was in breach of article $34, \S 4$ of the Constitution, which prohibits public authorities from engaging in any form of intrusion into communications other than in the cases provided for in criminal procedural law. ${ }^{251}$

In August 2017, Organic Law 4/2017 was published, regulating the access of SIS and SIED to telecommunications and Internet data outside criminal proceedings. The novelty in this legislative reformulation is judicial supervision and prior authorization for

\footnotetext{
${ }^{248}$ M. P. R. de Faria, “Anotação ao artigo 35. ${ }^{\circ}$, in J. Miranda e R. Medeiros, Constituição Portuguesa Anotada, vol. I, cit., pp. 779-801, pp. 796-798.

249 A.de S. Pinheiro, Privacy e protecção de dados pessoais: a construção dogmática do direito à identidade informacional, AAFDL Editora, Lisboa, 2015, p. 733. For more information on the CNPD, see: https://www.cnpd.pt/

${ }^{250}$ Opinion no. $51 / 2015$.

251 Ruling no. 403/15, $27^{\text {th }}$ of December, 2015.
} 
access to telecommunication and Internet data, carried out by a group of judges from the Supreme Court of Justice.

The CNPD, which had already decided against the previous legislation proposal, reaffirmed that, since access to data is carried out within the scope of criminal prevention, and therefore outside the constitutional scope of criminal proceedings by the SIS and SIED, both non-criminal investigation bodies, this act is still in violation of the aforementioned constitutional rules and principles. ${ }^{252}$ Even acknowledging that it is a "high-level judicial control", the CNPD problematizes its operability, because the absence of "a clear and standardized procedure (...) constitutes a very considerable obstacle to the legality and constitutionality of the remedy". More specifically, the legislation "infringes the prohibition of intrusion in the electronic communications provided for in the Constitution of the Portuguese Republic, as well as the rules of the Constitution, the Charter of Fundamental Rights of the European Union and the European Convention on Human Rights".

On the $14^{\text {th }}$ of August, the current President of the Republic Marcelo Rebelo de Sousa promulgated the diploma, invoking the "broad consensus was reached in order to overcome the doubts that had given rise to the previous request for preventive constitutional review", as well as "the relevance of the regime in question for the defence of the Democratic Rule of Law, in particular for the protection of fundamental rights». The radical-left parties (Communist Party and Left Bloc) requested successive control of constitutionality to the Portuguese Constitutional Court (articles 281 and 282)."253

On the $18^{\text {th }}$ September 2019, in a long ruling with several concurring and dissented opinions, the PCC declared some of the norms unconstitutional on the grounds of violation of articles $26, \S 1$ (personal rights), 35, $\S 1$ and 4 (use of information technology) and $18, \S 2$ (proportionality principle on the restriction of constitutional rights). ${ }^{254}$

\subsection{Legal traditions on free speech}

H. Patrick Glenn envisions 'legal tradition' as normative information. ${ }^{255}$ Accordingly, I can verify that freedom of speech is of paramount importance in the

\footnotetext{
252 Opinion no. 38/2017, 30 $0^{\text {th }}$ of May, 2017.

253 C. S. Botelho, "Portugal: The State of Liberal Democracy", cit., pp. 230-234.

254 No. 464/2019.

${ }^{255}$ H. Patrick Glenn, Legal Traditions of the World - Sustainable diversity in law, Oxford University Press, Oxford, 2014, p. 56. Pointing out some conceptual weaknesses of this thesis, see Thomas Duve, "Legal traditions: A dialogue between comparative law and comparative legal history", Comparative Legal History, 6 (1), 2018, pp. 15-33.
} 
current Portuguese historical and political contexts, after having endured almost five decades of dictatorship. Still, the commitment to freedom of speech is even deeper in the USA or Australia. Portugal's constitutional model, as Germany's or Brazil's, share the same inspirational source of human dignity. That is why some scholars jokingly argue that "Europeans are from Venus and Americans are from Mars"

Looking for some axiological grounding, some oppose European constitutionalism - a constitutionalism of dignity - to American constitutionalism, a constitutionalism of liberty ${ }^{257}$. To me, though, it seems somehow insular to see them as antagonistic legal concepts, since none of them truly exists without the other ${ }^{258}$. History teaches us why it is relevant to associate both concepts and stand up for a dignified freedom and free dignity ${ }^{259}$.

As previously stated, although PCC jurisprudence lacks leading cases regarding the place and meaning of freedom of speech, the Portuguese State has been frequently condemned by the European Court of Human Rights for limiting free speech.

Regarding religion, the Portuguese Constitution rules that the state should be guided by religious neutrality, which does not equal ignoring the religious phenomenon altogether.

\section{Freedom of movement}

\subsection{Does EU law give room to an autonomous national regulation?}

Article $8, \S 1$ and 2 of the Portuguese Constitution addresses the hierarchical relation between constitution and international law. In this sense, most global and regional international law norms will be placed beneath the constitution. ${ }^{260}$

\footnotetext{
${ }^{256}$ R. Kagan, Of Paradise and Power: America and Europe in the New World Order, apud J. E. K. Murkens, "Comparative Constitutional Law in the Courts: Reflections on the Originalists' Objections", Verfassung und Recht in Übersee, 41 (1), 2008, pp. 32-50, p. 36.

${ }^{257}$ D, P. Kommers, "Comparative Constitutional Law... cit., p. 64.

${ }^{258}$ C. S. Botelho, Os direitos sociais em tempos de crise, cit., p. 113.

${ }^{259}$ R. Medeiros, "Direitos, liberdades e garantias e direitos sociais: entre a unidade e a diversidade", Estudos em homenagem ao Prof. Doutor Sérvulo Correia (ed. J. Miranda), IV, Coimbra Editora, 2010, pp. 657683, em especial, pp. 659-660.

${ }^{260}$ Except for ius cogens norms, the Universal Declaration of Human Rights (article 16, § 2), and the European Union treaties. See F. U. Calvão, M. F. Campos \& C. S. Botelho, Introdução ao Direito Público,

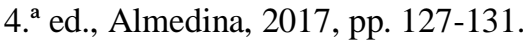


With respect to the relation between the Portuguese constitution and European Union law, article 7, $\S 6$ of the Constitution rules the following ${ }^{261}$ : "Subject to reciprocity and with respect for the fundamental principles of a democratic state based on the rule of law and for the principle of subsidiarity, and with a view to the achievement of the economic, social and territorial cohesion of an area of freedom, security and justice and the definition and implementation of a common external, security and defence policy, Portugal may agree to the joint exercise, in cooperation with the Union's institutions, of the powers needed to construct and deepen the European Union."

Yet, the "most profound adaptation" 262 of the Portuguese Constitution to European integration was through the constitutional amendment of 2004, which introduced article 8, $\S 4$ : “The provisions of the treaties that govern the European Union and the norms issued by its institutions in the exercise of their respective competences are applicable in Portuguese internal law in accordance with Union law and with respect for the fundamental principles of a democratic state based on the rule of law."

Before 2004, primacy of EU law over constitutional law was arguable, since article 277 clearly undermines with unconstitutionally "norms that contravene the provisions of the Constitution or the principles enshrined therein." Following the example of the Irish Constitution, ${ }^{263}$ the Portuguese Constitution joined the small group of European national constitutions which expressly recognize EU supremacy over national constitutional law. ${ }^{264}$

Article $8, \S 4$ "does not imply a constitutional surrender" 265 , but it stresses the primacy of European Union law over all national norms - constitutional or infraconstitutional - if "the fundamental principles of a democratic state based on the rule of law" are respected. ${ }^{266}$

Hence, the Portuguese Constitution recognizes the primacy of EU law "as long as both legal systems are compatible in systemic terms." ${ }^{267}$ As Miguel Poiares Maduro

\footnotetext{
${ }^{261}$ Added in the constitutional amendment of 1992 and expanded (in 2001) to accommodate the third pillar of Maastricht.

${ }^{262}$ V. Moreira, “A CRP e a União Europeia”, cit., p. 881.

263 Article 29, § 6.

${ }^{264}$ Idem, p. 882.

${ }^{265}$ F. P. Coutinho and N. Piçarra, "Portugal: The Impact of European Integration... cit., p. 606. Similarly, M. L. Duarte, "Sobre o caso Gauweiler. Estará o Tribunal de Justiça pronto a fazer o que for necessário para preservar o primado da União Europeia?", Estudos em Homenagem ao Conselheiro Presidente Rui Moura Ramos, Almedina, Coimbra, vol. I, 2016, pp. 749-765, p. 763.

${ }^{266}$ C. S. Botelho, "Novo ou velho direito?... cit., p. 59.

${ }^{267}$ F. P. Coutinho and N. Piçarra, "Portugal: The Impact of European Integration... cit., p. 602.
} 
metaphorically described, "contra-punctual legal techniques" harmonize different melodies (law systems) which are not in a hierarchical relation. ${ }^{268}$

During almost five decades of the right-wing authoritarian regime of Salazar (“Estado Novo"), until 1974, freedom of movement was highly restricted. Although hundreds of thousands of Portuguese escaped to France, Canada, United States and other destinations, illegal emigration was then considered a crime punishable with jail time. ${ }^{269}$

In the current Portuguese Constitution, freedom of movement is deeply connected with other constitutional rights, such as Right to freedom and security (article 27), freedom of conscience, of religion and of form of worship (article 41), right to meet and to demonstrate (article 45), freedom to choose a profession and of access to the public service (article 47), right to work (article 58), or the right to education, culture and science (article 73). ${ }^{270}$

Article $44, \S 1$ grants every citizen the right to travel and settle freely in any part of Portuguese territory. Additionally, every citizen is guaranteed the right to emigrate or to leave Portuguese territory and the right to return thereto" (article 44, § 2). Considering EU competence on the subject, the scope left for the national regulation of this right is very limited. In fact, the Portuguese state has autonomy regarding immigration from outside de EU.

Still, both freedom of movement and the Portuguese legal economic arena are not entirely parallel to the EU arena: $(i)$ the European principles in this matter are very abstract; (ii) there is always some degree of flexibility while implementing EU legislation. ${ }^{271}$

\subsection{Legal traditions on freedom of movement}

There is no resistance to the supranational push towards an EU-wide guarantee of freedom of movement. Again, there are no national rules in place against social dumping or eco-dumping. Industrial policy is extremely dependent on EU law.

\footnotetext{
268 M. P. Maduro, A Constituição Plural - Constitucionalismo e União Europeia, Principia, Cascais, 2006, pp. 50-51, and "Europe and the constitution: what if this is as good as it gets?", European Constitutionalism beyond the State (eds. J. H. H. Weiler and M. Wind), Cambridge University Press, 2019, pp 74-102. Adhering to Maduro's methodological approach, see J. Komárek, "European Constitutionalism and the European Arrest Warrant: In Search of Limits of "Contrapuntal Principles", Common Market Law Review, 44, 2007, pp. 30-39.

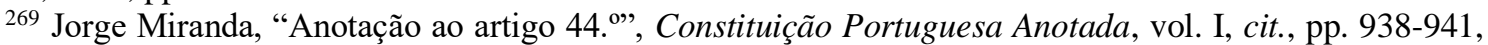
p. 939.

${ }^{270}$ Idem, ibidem.

${ }^{271}$ Luís S. Cabral de Moncada, Direito Económico, Almedina, Coimbra, $7^{\text {th }}$ ed., 2018, p. 128.
} 
As to the existence of rules against industrial relocation abroad, this subject is related to international trade and, therefore, regulated by the World Trade Organization. Still, Portugal allows inbound and outbound cross-border transfers of a company’s seat. ${ }^{272}$ With respect to the Portuguese economic Constitution and as explained before (I. 2.3), some doctrine considers several constitutional norms to be obsolete and not in tune with EU law. ${ }^{273}$ As examples, one can mention paragraph $c$ ) of article 80 (freedom of entrepreneurial initiative and organisation, within the overall framework of a mixed economy), article 87 (foreign economic activity and investment), or even paragraph $g$ ) of article 288 (the existence of economic plans, within the framework of a mixed economy).

\section{Judicial independence}

\subsection{Judiciary organization in Portugal}

The Portuguese Constitutional Court (PCC) is the court "with the specific competence to administer justice in matters of a constitutional-law nature" (article 221). It is composed of thirteen Justices, ten of whom are appointed by the Assembly of the Republic (which requires a two-thirds majority) and three are co-opted by those ten (article 222, § 1). Six of the judges (either appointed by the parliament or are co-opted) are necessarily career magistrates (mostly from the Supreme Court of Justice or from the Supreme Administrative Court). The other six are jurists, usually law professors, or professional politicians with a law degree (article $222, \S 2$ ).

The elected judges tend to reflect the political composition of the parliament at the time of the election, as their names are extracted from a unique list negotiated by the main

\footnotetext{
272 A. Frada de Sousa, “A Company's Cross-border Transfer of Seat in the EU after Cartesio", Jean Monnet Working Paper 7/09, 2009, pp. 1-83, pp. 10-11: "Portuguese Law for example, allows, since 1986, companies to transfer their seat, both to and from Portugal, with a change of their lex societatis, provided that certain requirements are fulfilled. Since the divergence between the real seat and the statutory seat of a company is possible under Portuguese Law, both the inbound and the outbound transfer of the real seat of the company alone are allowed, without the company's loss of legal personality. The company will, in principle, continue to be subject to the law of the State where the statutory seat is located in result of the presumption of coincidence between its statutory seat and its real seat. The crossborder transfer of the statutory seat alone of a company is also admitted. Such transfer will trigger a change of lex societatis and a change of the company's form in a case of inbound transfer of seat to Portugal. One must not exclude, however, that if it becomes clear that the 'real seat' of the company is situated in another State, the law of this State will ultimately apply, in particular as regards the internal affairs of the company.

${ }^{273}$ See Luís S. Cabral de Moncada, op. cit., p. 129.
} 
parties. Thus, the PCC "broadly reflects parliamentary preferences without major bias against either of the two main blocks (left or right)." 274

Constitutional judges are elected for a non-renewable term of nine years (before 1997's constitutional amendment, the mandate was for six years and renewable for a second period in office). ${ }^{275}$

Under article 209, § 1 of the Constitution, "in addition to the Constitutional Court, there shall be the following categories of court: a) The Supreme Court of Justice and the courts of law of first and second instance; ${ }^{276}$ b) The Supreme Administrative Court and the remaining administrative and tax courts $;{ }^{277}$ c) The Court of Auditors". ${ }^{278}$ In addition, provisions are also made for "maritime courts, arbitration tribunals and justices of the peace." (article 209, § 2).

The ordinary courts with civil and criminal jurisdiction are the judicial courts, which are organized in a descending order of hierarchical rank and territorial scope: the Supreme Court (with jurisdiction over the entire country), the courts of appeal (per judicial district) and the district courts (first instance).

The Supreme Court of Justice, currently constituted by around 60 Justices, is the higher body in the hierarchy of judicial courts, and functions as a Plenary Court, in Plenary Specialized Chambers, and by Chambers. ${ }^{279}$ The Plenary Specialized Chambers function on the same terms as the Plenary Court and are competent to judge the President of the Republic, the President of the Assembly of the Republic, and the Prime Minister for any crime committed during the term of their office. It is the chambers' duty, according to their respective specialization, to judge cases of crimes committed by judges of the Supreme Court of Justice, judges of the Courts of Appeal, and magistrates of the Public Prosecutor's Office working in such Courts, or persons treated as such, as well as actions forwarded against them because of their duties.

Access to the position of judge near the Supreme Court of Justice is made through a merit curricular invitation by judges of the Courts of Appeal, to magistrates belonging to the Public Prosecutor's Office, and to other jurists of merit, on the following proportion

274 S. Amaral-Garcia, N. Garoupa, and V. Grembi, "Judicial Independence and Party Politics in the Kelsenian Constitutional Courts: The Case of Portugal”, Journal of Empirical Legal Studies, 6 (2), 2009, pp. 381-404.

${ }_{275}$ Article 222, $\S 3$ of the Constitution.

276 Articles 210 and 211 of the Constitution.

277 Article 213 of the Constitution.

278 Article 214 of the Constitution.

${ }^{279}$ About the Court: https://www.stj.pt/ 
for each five vacancies: three for the first ones, one for the second ones, and one for the latter. The judges of the Courts of Appeal who are in the first fourth of the seniority list, and do not officially waive the invitation to tender, are necessary contesters; the remaining are deemed voluntary contesters.

The President of Supreme Court of Justice is elected by its Justices (article 210, $\S$ 1), by secret ballot, for a three-year term of office, which can be renewable once by reelection. The President of the Supreme Court of Justice is also, inherently, the President of the Higher Judicial Council, which is the management disciplinary body of the judicature (judicial appointments, placements, transfers and promotions). The Council is composed by two councillors appointed by the President of the Republic, seven councillors elected by Parliament, and seven judges elected by their peers.

The Supreme Administrative Court is the senior organ in the hierarchy of administrative and tax courts (article 212, $\S 1$ ). ${ }^{280}$ The administrative courts include the first instance administrative and tax courts, the central administrative courts (North and South) and the Supreme Administrative Court (covering the whole country). Conflicts of jurisdiction between courts are resolved by a Conflict Court, regulated by law.

The Superior Council of Administrative and Tax Courts is chaired by the President of the Supreme Administrative Court and composed of the following members: two appointed by the President of the Republic; four elected by the Assembly of the Republic; and four judges elected by their peers, in accordance with the principle of proportional representation". 281

Taking into consideration the PCC and the ordinary supreme courts, it is relevant to mention that there is no "campaign" or lobbying, nor the issue of campaign finance for judicial elections.

Regarding judicial councils in general, some scholars worry that judicial councils mainly composed by magistrates might hinder accountability and be used to pursue the corporate interests of magistrates. ${ }^{282}$ In several states, such as in Italy, Spain, Portugal and France, measures have been taken in order to prevent the politization of these autonomous judicial bodies. ${ }^{283}$

\footnotetext{
${ }^{280}$ About the Court: https://www.stadministrativo.pt/

${ }^{281}$ Article 75 of Law no. 13/2002, 19.02.2002.

282 G. D. Federico, "Judicial Independence in Italy”, Judicial Independence in Transition (ed. A. SeibertFohr), Springer, 2012, pp. 357-402.

283 A. Seibert-Fohr, "Judicial Independence - The Normativity of an Evolving Transnational Principle", Judicial Independence in Transition (ed. A. Seibert-Fohr), Springer, 2012, pp. 1279-1362, C. Guarnieri, "Judicial Independence of Latin Countries of Western Europe", Judicial independence in the age of
} 
In Portugal, the Higher Judicial Council is chaired by the President of the Supreme Court of Justice and also comprises the following ordinary members: two members appointed by the President of the Republic; seven elected by the Assembly of the Republic, and seven judges elected by their peers in harmony with the principle of proportional representation (article 218, § 1).

The judicial councils are competent for the recruitment of judicial personnel, on matters of professional evaluation for the promotion of judges, and for disciplining judges as well (article 214). Their main goal is the promotion and protection of judicial independence. Judicial and administrative judges are appointed for life and cannot exercise another public or private job.

\subsection{Judicial independence}

Articles 202-224 of the Portuguese Constitution outline the principles underlying the administration of justice and the workings of the courts in Portugal. Courts are "the entities that exercise sovereignty with the competence to administer justice in the name of the people" (article 202, § 1). Furthermore, "courts are independent and subject only to the law" (article 203).

Judicial independence is of paramount importance to the right to an effective remedy and fair trial. In the case Associação Sindical dos Juizes Portugueses, the ECJ ruled that "the principle of the effective judicial protection of individuals' rights under EU law (...) is a general principle of EU law stemming from the constitutional traditions common to the Member States". ${ }^{284}$ In this sense, "the factors to be taken into account in assessing whether a body is a 'court or tribunal' include, inter alia, whether the body is established by law, whether it is permanent, whether its jurisdiction is compulsory, whether its procedure is inter partes, whether it applies rules of law and whether it is independent."285

Although in many civil law states (contrary to common law states) the executive is primarily responsible for court administration, in Portugal, court administration is the

\footnotetext{
democracy - Critical perspectives from around the world (ed. P. H. Russell \& D. M. O'Brien), University Press of Virginia, 2001, pp. 111-130, and S. A. Garcia and N. Garoupa, "Algumas notas sobre a governança judiciária - Uma análise comparativa entre o Conselho Superior da Magistratura, o Conselho Superior dos Tribunais Administrativos e Fiscais e o Consejo General del Poder Judicial”, Julgar, 2, 2007, pp. 167-184. ${ }^{284}$ ECJ, C-64/12, 28.02.2018.

${ }^{285}$ Para. 38.
} 
responsibility of the judiciary. ${ }^{286}$ In fact, "there are certain indications that with respect to formal guarantees of judicial independence, Italy, Portugal, and Spain differ significantly from the other civil law countries, in providing for appointment of judges by and vesting responsibility for court administration in a judicial body."287

In Portugal, the existence of independent judicial councils is not an undemocratic judicial self-government in which judges can largely determine decisions about their careers and discipline. Instead, what we have is an autonomous judicial government, separated from the executive, in which judges are in the minority vis-à-vis the members elected by Parliament and appointed by the President of the Republic, by criteria of political convenience. Therefore, de jure and de facto, judicial councils are controlled by the organs of sovereignty directly legitimized by the vote: the President and the parliament. $^{288}$

Additionally, the Government exercises budgetary control over the activity of the judiciary (including hiring staff and technical experts), which decisively influences not only judicial proficiency, but also the ability of a court to deliver its judgments in a reasonable time. The budget of the courts is prepared by the Ministry of Justice, according to information given by each law court. ${ }^{289}$ However, the Minister of Justice does not have any power over the activity of the judges. The Union Association of Judicial Magistrates is registered in the Ministry of Labour.

Regarding disputes involving the highest authorities of the state, there are some special provisions. According to article 130, "The President of the Republic answers before the Supreme Court of Justice for crimes committed in the exercise of his functions. 2. Proceedings may only be initiated by the Assembly of the Republic upon a motion subscribed by one fifth and a decision passed by a two-thirds majority of all the Members of the Assembly of the Republic in full exercise of their office. 3. Conviction implies removal from office and disqualification from re-election. 4. For crimes that are not

\footnotetext{
286 S. Shetreet, "Judicial Independence: New Conceptual Dimensions and Contemporary Challenges", Judicial Independence: The Contemporary Debate (ed. S. Shetreet and J. Deschênes), Martinus Nijhoff Publishers, Dordrecht, 1985, pp. 590-681, p. 624.

${ }^{287}$ J. Ginter, "Guarantees of Judicial Independence", Juridica International Law Review, 1996, pp. 75-84, p. 84 , fn. 67.

288 M. Soares, “O corporativismo dos juízes”, Público, 19.06.2019, available at: https://www.publico.pt/2019/06/19/sociedade/opiniao/corporativismo-juizes-1876895?fbclid=IwAR0xpaO7t-AA77PZ7kuMdrp_09pIXn7NoITlhOlg-KZdbm94_NWhl1gZyw

${ }^{289}$ A. M. P. Vaz, "Portugal”, Judicial Independence: The Contemporary Debate (ed. S. Shetreet and J. Deschênes), Martinus Nijhoff Publishers, Dordrecht, 1985, pp. 278-287.
} 
committed in the exercise of his functions, the President of the Republic answers before the common courts, once his term of office has ended."

As to members of the parliament, they "are not civilly or criminally liable for or subject to disciplinary proceedings in relation to their votes or the opinions they express in the exercise of their functions" (article 157, § 1). In the event that "criminal proceedings are brought against any member of the Assembly of the Republic and he is definitively charged, the Assembly shall decide whether or not he must be suspended so that the proceedings can take their course" (article 157, §4).

Focusing on the Portuguese government, which comprises "the Prime Minister, the Ministers and the Secretaries and Under Secretaries of State" (article 183, § 1), "no member of the Government may be detained, arrested or imprisoned without the authorization of the Assembly of the Republic, except for a wilful crime punishable by imprisonment for more than three years and in flagrante delicto" (article 196, § 1).

\subsection{Legal traditions on judicial independence}

Court' independence is a core guarantee of the democratic rule of law and umbilically linked with the separation of powers (article 2). In fact, to avoid political interference in the selection and day-to-day activity of the courts, the Portuguese Constitution grants courts full independence, not only towards other sovereign organs, but also among themselves (besides courts hierarchy). ${ }^{290}$

Portuguese independent judicial councils are a form of an autonomous judicial government and are de jure and de facto controlled by the organs of sovereignty directly legitimized by the vote, such as the President of the Republic and the parliament.

${ }^{290}$ J. J. G. Canotilho and V. Moreira, A Constituição da República Portuguesa Anotada, II, cit., p. 513. 